\title{
Particulate Trace Element Export in the North Atlantic (GEOTRACES GA01 Transect, GEOVIDE Cruise)
}

Lemaitre Nolwenn 1, 2, 3, ${ }^{\star}$, Planquette Helene ${ }^{2}$, Dehairs Frank ${ }^{3}$, Planchon Frederic ${ }^{2}$, Sarthou Geraldine ${ }^{2}$, Gallinari Morgane ${ }^{2}$, Roig Stéphane ${ }^{2}$, Jeandel Catherine ${ }^{4}$, Castrillejo Maxi 5

1 Institute of Geochemistry and Petrology, ETH-Zurich, Clausiusstrasse 25, 8092 Zurich, Switzerland

${ }^{2}$ CNRS, Université de Brest, IRD, Ifremer, LEMAR, Technopôle Brest-Iroise, 29280 Plouzané, France

${ }^{3}$ Analytical, Environmental, and Geo-Chemistry, Vrije Universiteit Brussel, Pleinlaan, 1050 Brussels, Belgium

${ }^{4}$ LEGOS, Université de Toulouse (CNRS/CNES/IRD/UPS), Observatoire Midi Pyrénées, 31400

Toulouse, France

${ }^{5}$ Laboratory of Ion Beam Physics, ETH-Zurich, Otto Stern Weg 5, 8093 Zurich, Switzerland

* Corresponding author : Nolwenn Lemaitre, email address : nolwenn.lemaitre@erdw.ethz.ch

\begin{abstract}
:
Vertical export of particulate trace elements (pTEs) is a critically underconstrained aspect of their biogeochemistry. Here, we combine elemental analyses on large $(>53 \mu \mathrm{m})$ particles and 234Th measurements to determine downward export fluxes from the upper layers $(40-110 \mathrm{~m}$ ) of pTEs (Al, Cd, $\mathrm{Co}, \mathrm{Cu}, \mathrm{Fe}, \mathrm{Mn}, \mathrm{Ni}, \mathrm{P}, \mathrm{Ti}, \mathrm{V}, \mathrm{Zn}$ ) and mineral phases (lithogenic, Fe- and Mn-oxides, calcium carbonate, and opal) in the North Atlantic along the GEOVIDE transect (Portugal-Greenland-Canada; GEOTRACES GA01 cruise). The role of lithogenic particles in controlling TE fluxes is obvious at proximity of the lberian margin where the highest pTE export fluxes were estimated (up to $3912 \mu \mathrm{g} / \mathrm{m} 2 / \mathrm{d}$ for pFe). However, high lithogenic and pTE fluxes are also observed up to $1700 \mathrm{~km}$ off this margin in the west European and Icelandic basins (up to $931 \mu \mathrm{g} / \mathrm{m} 2 / \mathrm{d}$ for pFe). The lowest pTE export fluxes are determined in the Labrador Sea (as low as $501 \mu \mathrm{g} / \mathrm{m} 2 / \mathrm{d}$ for $\mathrm{pFe}$ ). High $\mathrm{Mn}$ - and Fe-oxide fluxes are estimated at the open ocean stations, suggesting that authigenic particles are an important vector of pTEs. All along the transect, biogenic particles also drive the pTE export fluxes, as shown by the similar pTE/POC ratios between exports and phytoplankton quotas. The shortest residence times (dissolved + particulate) are generally observed where lithogenic particles control the pTE fluxes (as low as 2 days for Fe) whereas pTEs seem to be longer retained when the contribution of biogenic particles become greater (residence times up to 147 days for $\mathrm{Fe}$ ).
\end{abstract}

Keywords: particulate trace elements, export fluxes, multiple carrier phases, residence times, GEOTRACES 


\section{INTRODUCTION}

41 Bioactive trace elements (TEs: $\mathrm{Cd}, \mathrm{Co}, \mathrm{Cu}, \mathrm{Fe}, \mathrm{Mn}, \mathrm{Ni}, \mathrm{Zn}$, etc.) are important for the marine primary productivity ${ }^{1}$, as they are required for numerous metabolic processes ${ }^{2,3}$. Sometimes in line with other bioactive trace elements, depleted Fe concentrations in the surface waters can

44 limit the phytoplankton, thus influencing the community structure and, as a result, the overall marine carbon cycle ${ }^{4,5}$. Therefore, the quantification of biogeochemical processes regulating the internal cycle of TEs is essential to better understand the carbon cycle and in particular the biological carbon pump ${ }^{6,7}$.

Many TEs reach the ocean through particles, either via atmospheric dusts ${ }^{8}$, rivers ${ }^{9}$, margins

${ }^{10}$ or sediments ${ }^{11}$. Marine particles also participate in the removal of TEs, either through scavenging onto particle surfaces ${ }^{12}$, precipitation of authigenic minerals such as barite ${ }^{13-15}$ and $\mathrm{Mn}$-Fe oxyhydroxides ${ }^{16}$, or sinking to the deep ocean due to lithogenic and biogenic ballast minerals ${ }^{17-19}$. Small (suspended; $1-53 \mu \mathrm{m}$ diameter) particles mainly trap TEs via scavenging, though they have been shown to slowly sink after coagulation to other particles ${ }^{20,21}$. Large

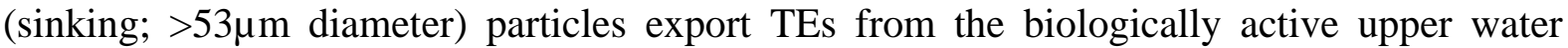
column down to the interior ocean ${ }^{22}$, with the remineralization length scale controlling the release of TEs into solution and their subsequent return to the surface. Earlier studies have revealed that particulate phosphorous $(\mathrm{pP})$, nickel $(\mathrm{pNi})$, zinc $(\mathrm{pZn})$ and organic carbon $(\mathrm{POC})$ are remineralized faster than particulate iron $(\mathrm{pFe})$ because of a stronger scavenging of dissolved Fe onto particles ${ }^{23,24}$. Thus, particle-solute interactions determine the residence times of TEs in the water column. However these residence times are presently not well known because of scarce estimates of TE inventories and fluxes into or out of the water column ${ }^{25}$. Despite an increasing number of studies addressing TE export, this process remains still poorly understood ${ }^{23,26,35,36,27-34}$. Besides the strong temporal and spatial variability, another reason

64 likely resides in the difficulty in measuring particulate trace element (pTE) fluxes, as TEs are 
present at very low concentrations in the ocean and are easily prone to contamination. Sediment traps are used to directly quantify the pTE export fluxes ${ }^{29,30,37,38}$ but their deployment tends to be time- and effort-intensive. They also can be biased because of lateral advection or because of possible TE contamination from the preservative solution added into the cups to avoid zooplankton and microbial activities ${ }^{39}$. One alternative for determining particulate export fluxes is the clean but indirect ${ }^{234} \mathrm{Th}^{238} \mathrm{U}$ method ${ }^{40-42} \cdot{ }^{234} \mathrm{Th}$ is a highly particle-reactive element with a short half-life $\left(\mathrm{t} 1 / 2=24.1\right.$ days) compared to its radioactive parent ${ }^{238} \mathrm{U}(\mathrm{t} 1 / 2=$ 4.47 billion years). While both isotopes are usually at secular equilibrium in subsurface waters, a deficit of ${ }^{234} \mathrm{Th}$ relative to ${ }^{238} \mathrm{U}$ can be observed in the upper ocean, where sinking particles carry ${ }^{234} \mathrm{Th}$ downward. This deficit of ${ }^{234} \mathrm{Th}$ relative to ${ }^{238} \mathrm{U}$ can be converted into an elemental export flux when multiplied with the ratio of the element to ${ }^{234} \mathrm{Th}$ (element: ${ }^{234} \mathrm{Th}$ hereafter) in the particulate material at a given depth ${ }^{34,41}$. This method has the benefit to allow flux determination at multiple stations and for a large suite of elements and mineral phases.

The presence of lithogenic and biogenic minerals, as well as oxyhydroxides, are identified as phases liable to control the settling of particles with depth ${ }^{19}$. In the temperate north Atlantic, advection of lithogenic material from continental margins and pronounced seasonal phytoplankton blooms strongly enhance the pTE distributions and downward export fluxes ${ }^{43-}$ 47. However, occasional lack of nutrients such as dissolved iron $(\mathrm{dFe}){ }^{48}$ can limit the primary productivity, the magnitude of the downward fluxes and thus the strength of the biological carbon pump ${ }^{5,49,50}$. This is well illustrated in the subtropical north Atlantic, which is characterized by oligotrophic conditions leading to low primary production ${ }^{51}$ and to low export 86 fluxes of POC ${ }^{52,53}$ and pTEs ${ }^{43}$. In this region, exports of POC ${ }^{54-58}$ and pTEs ${ }^{28}$ show episodic

87 fluctuations along the season due to nutrient and/or light limitations but also due to lithogenic inputs mainly originating from margins or associated with atmospheric dust depositions 
because of the decreasing influence of the Saharan dust plume ${ }^{43}$. Nevertheless, lateral supplies of lithogenic material from continental shelves have been reported and could enhance the export fluxes ${ }^{28,34}$

In this study, we aim to better understand the processes controlling the TE distributions in the upper layers of the North Atlantic Ocean by focusing on particulate TE export. The different particulate substrates (authigenic, lithogenic and biogenic) liable to carry the pTEs are investigated and the export efficiencies are evaluated by estimating the residence times of TEs within the upper ocean.

\section{METHODS}

\subsection{Biogeochemical characteristics of investigated stations}

Fieldwork was conducted on board the French $R / V$ Pourquoi Pas? along the GEOTRACES GA01 section during the GEOVIDE expedition (Fig. 1). The cruise was carried out in MayJune 2014. We sampled a total of 11 stations located in five different biogeochemical domains described in details in Lemaitre et al. (2018) ${ }^{60}$ and in Table 1. Briefly, the Iberian basin was sampled after the spring bloom and was characterized by a low primary productivity (PP) ${ }^{61}$. Station \#13 had the highest proportion of cyanobacteria (12\% of phytoplankton abundance) of the all transect ${ }^{62}$. Particulate organic carbon (POC) export was high at Station \#1 while low at Station \#13, reflecting the low nutrient availability in subtropical waters ${ }^{60}$. The west European (Stations \#21 and \#26) and Icelandic (Stations \#32 and \#38) basins were sampled during the bloom development and were the most productive areas with the highest PP observed along the transect ${ }^{60}$. Diatoms dominated the phytoplankton community (41\% of phytoplankton abundance) but dinoflagellates and haptophytes (including coccolitophorids) also contributed significantly in the west European basin ( 20\% of phytoplankton abundance ${ }^{62}$ ). Conversely, nano-phytoplankon and mainly haptophytes dominated the community in the Icelandic basin. 
115 High POC exports were determined in both basins and particularly at Station \#32 ${ }^{60}$. The 116 Irminger basin (Stations \#44 and \#51) was sampled close to the bloom maximum and PP values

117 were high, with a clear dominance of diatoms (between 55 and $77 \%$ of phytoplankton

118 abundance ${ }^{62}$ ). Because of the accumulation of biomass in the surface waters, POC export 119 fluxes were low, with Station \#44 having the lowest one of the entire cruise ${ }^{60}$. The Labrador basin (Stations \#64, \#69 and \#77) was sampled after the PP peak, at the onset of the bloom decline ${ }^{60}$. Productivity was relatively low compared to the other studied basins. Diatoms were also dominating, contributing up to $62 \%$ of the phytoplankton abundance ${ }^{62}$. POC export fluxes were relatively high, likely because of the increasing number of rapidly sinking particles ${ }^{60}$.

2.2. Particle sampling

Total ${ }^{234} \mathrm{Th}$ activities were determined from $4 \mathrm{~L}$ unfiltered seawater sampled with $12 \mathrm{~L}$ Niskin bottles mounted on CTD rosette and were processed following the method of Pike et al. (2005) ${ }^{63}$. Samples were acidified and spiked with a ${ }^{230} \mathrm{Th}$ yield monitor in order to estimate the ${ }^{234} \mathrm{Th}$ recovery during sample processing. After a $12 \mathrm{~h}$ equilibration, $\mathrm{pH}$ was increased and $\mathrm{KMnO}_{4}$ and $\mathrm{MnCl}_{2}$ solutions were added. After a further $12 \mathrm{~h}$ equilibration, samples were filtered on quartz-microfiber discs (QMA, Sartorius, nominal porosity $=1 \mu \mathrm{m}$, diameter $=25 \mathrm{~mm}$ ) and the ${ }^{234} \mathrm{Th}$ activities were measured on-board using a low-level beta counter (RIS $\varnothing 囚$, Denmark). Residual beta activities were measured $\sim 6$ months after the cruise after which samples were processed for Th recoveries using ${ }^{229} \mathrm{Th}$ as a second yield tracer. Export fluxes of ${ }^{234} \mathrm{Th}$ were then calculated using a 1-D box model ${ }^{64}$ under steady state assumptions and neglecting advection and diffusion ${ }^{41}$. Export fluxes of ${ }^{234} \mathrm{Th}$ are presented in Lemaitre et al (2018) ${ }^{60}$. Particulate matter for biogenic silica $(\mathrm{BSi})$, calcium carbonate $\left(\mathrm{CaCO}_{3}\right)$ and pTE analyses was collected on the same in-situ pump (Challenger Oceanics ${ }^{\circledR}$ and McLane ${ }^{\circledR}$ pumps, ISP) filter, whereas particles for POC were collected using a separate filter holder. The later was mounted either on a second flow path when modified McLane ISP heads were used, or with a separate 
141 ISP unit ${ }^{60}$ attached 10 to $50 \mathrm{~m}$ apart from the ISP dedicated to TEs (see Table S1). Particulate

$142{ }^{234} \mathrm{Th}$ activity in the large size particle fraction (LSF, >53 $\mu \mathrm{m}$ ) was determined on particles 143 collected with each ISP system (Fig. S1).

144 Particulate organic carbon (POC) LSF was collected on a 53- $\mu$ m mesh polyester screen (Petex), 145 which was cut into quarters. Particles present on one quarter of the Petex screen were rinsed146 off using $0.45 \mu \mathrm{m}$ filtered seawater obtained during the cruise and subsequently collected on a 147 silver filter (SterliTech, nominal porosity $=0.45 \mu \mathrm{m}$, diameter $=25 \mathrm{~mm}$ ) for one quarter, and on $148 \mathrm{a} \mathrm{GF} / \mathrm{F}$ filter (Whatman, nominal porosity $=0.7 \mu \mathrm{m}$, diameter=25 $\mathrm{mm}$ ) for another quarter, 149 before being Beta-counted on board. Back in the home laboratory, samples were prepared for 150 POC analyses: filters were fumed with $\mathrm{HCl}$ vapor, dried, packed in pre-combusted silver cups 151 and analysed with an elemental analyser (EA-IRMS, Delta V Plus, Thermo Scientific). More 152 details on POC and particulate ${ }^{234} \mathrm{Th}\left(\mathrm{p}^{234} \mathrm{Th}\right)$ analyses can be found in Lemaitre et al. (2018) $153 \quad 60$.

154 Particulate matter for $\mathrm{BSi}, \mathrm{CaCO}_{3}$ and $\mathrm{pTE}$ determinations was filtered on a $142 \mathrm{~mm}$-diameter $15553-\mu \mathrm{m}$ mesh polyester screen (Petex) for the LSF upstream of a $142 \mathrm{~mm}$-diameter $0.8-\mu \mathrm{m}$ 156 polyethersulfone filter (Supor®) for the small size particle fraction (SSF). Before use, filters 157 were soaked in $1.2 \mathrm{M} \mathrm{HCl}$ (Suprapur grade, Merck), heated overnight at $60^{\circ} \mathrm{C}$ and subsequently 158 rinsed with Milli-Q grade water. On board, filters were processed under a laminar flow unit 159 within a customized clean "bubble" to prevent contamination. Before and after the ISP 160 recoveries, pump heads were protected with plastic bags to minimize contamination. After 161 pump recoveries, filter heads were dismantled and carried inside the clean bubble.

162 Using a clean ceramic scalpel, one quarter of the Petex screen, dedicated to $\mathrm{p}^{234} \mathrm{Th}$ and BSi 163 analyses, was cut out. Particles were washed off the Petex screen using $0.45-\mu \mathrm{m}$ filtered 164 seawater obtained during the cruise. Particles were then collected on polycarbonate filters (PC; 165 Nuclepore ${ }^{\circledR}$, porosity $=0.4 \mu \mathrm{m}$, diameter $=25 \mathrm{~mm}$ ) mounted on a polysulfone filtration unit. 
Filters were left to dry at room temperature inside the laminar flow unit and subsequently prepared for Beta counting. Activities of $\mathrm{p}^{234} \mathrm{Th}$ were also determined on a second quarter of the Petex screen: particles were washed off, using the $0.45-\mu \mathrm{m}$ filtered seawater, and collected on a polyethersulfone filter (Supor ${ }^{\circledR}$, porosity $=0.45 \mu \mathrm{m}$, diameter $=25 \mathrm{~mm}$ ) mounted on a Nalgene filtration unit (Fig. S1). Because Beta counting of samples is probably incompatible with trace metal clean stringent conditions, the two last quarters of the Petex screen, dedicated to pTEs, particulate calcium ( $\mathrm{pCa}$ ) and sodium ( $\mathrm{pNa}$ ), were stored in a clean petrislide (Pall Gelman) and kept at $-20^{\circ} \mathrm{C}$ until sample processing and analysis in the home laboratory. Since Supor filters with the SSF were not Beta counted, there are no data for the SSF $\mathrm{p}^{234} \mathrm{Th}$ activity.

\subsection{Particulate matter analyses}

177

The methods used here have been approved during a GEOTRACES intercalibration exercise and our elemental concentrations have been submitted to the GEOTRACES Intermediate Data Product (IDP) 2021. The concentrations obtained from ISP sampling (this study) have been compared to those obtained by GO-FLO sampling at the same locations (from Gourain et al., $2019^{65}$ and from Planquette et al., personal communication, 2019). Both datasets were obtained after using exactly the same digestion and analytical methods. Although similar element profiles were obtained from both datasets, highlighting data consistency, we note that pTE concentrations obtained from ISP sampling were generally lower than those obtained from GO-

185 FLO bottles. This discrepancy could possibly result from particle washout during ISP recovery, since our ISPs were not systematically equipped with anti-washout systems, or due to some loss when transferring particles from the Petex screens to other filters (see above). To limit these effects, our study focuses on elemental ratios and on element: ${ }^{234} \mathrm{Th}$ ratios, rather than on concentrations or activities. 
191 In the home laboratory the two remaining quarters of Petex screen saved for pTEs, pCa and $192 \mathrm{pNa}$ analyses were washed off with $0.45-\mu \mathrm{m}$ filtered, low TE surface seawater collected during 193 the GEOVIDE cruise (Station \#77, 40m, filtered through a Supor filter, $0.45 \mu \mathrm{m}$ ) and 194 subsequently collected on acid cleaned 47-mm diameter mixed cellulose esters filters (MF195 Millipore ${ }^{\circledR}$ filters, $0.8 \mu \mathrm{m}$ ), using Nalgene ${ }^{\circledR}$ filtration units (Fig. S1). Then, filters were 196 processed following the protocol of Planquette and Sherrell (2012) ${ }^{66}$. Briefly, one half of the MF filter was kept in a clean petrislide while the other half was placed along the wall of an acid cleaned Teflon vial (Savillex $\left.{ }^{\circledR}\right)$ and digested with a $\mathrm{HNO}_{3} 8 \mathrm{M}$ - HF $2.3 \mathrm{M}$ mix solution (Ultrapur and Suprapur grades, respectively, Merck ${ }^{\circledR}$ ), refluxing at $130^{\circ} \mathrm{C}$ during $4 \mathrm{~h}$. After gentle evaporation close to near dryness, $200 \mu \mathrm{L}$ of concentrated $\mathrm{HNO}_{3}$ (Ultrapur grade, Merck) was added in order to drive off the fluorides. The residue was brought back into solution 202 with $0.32 \mathrm{M} \mathrm{HNO} 3$ spiked with $1 \mu \mathrm{g} / \mathrm{L}$ of indium and stored in acid cleaned centrifuge tubes (Corning®). Measurements of pTEs were performed using a sector field inductively coupled mass spectrometer (SF-ICP-MS, Element 2, Thermo). External calibration curves were run at the start, middle and end of the sequence. The precision and accuracy of our measurements were assessed by analysing the certified reference material (CRM) BCR-414. Recoveries were typically within $10 \%$ of the certified values and the precision, given by the relative standard deviation of the five CRM analyses, was between 0.2 and $24 \%$ depending on the element (Table 2). Gourain et al. (2019) analysed two other CRM (PACS-3 and MESS-4) by using the exact 210 same analytical method and found similar accuracy and precision results ${ }^{65}$. The reproducibility 211 of our analyses was assessed by analytical replicates of 17 samples and differences between 212 replicates were less than $6 \%$ from the mean value.

213 Aluminium (Al) is usually used as a tracer of lithogenic particles because of its high crustal 214 abundance (Upper Continental Crust or UCC Al $=8.04 \%$ by weight ${ }^{67}$ ) and its stable 
215 concentrations among lithogenic sources. However, Al has been shown to be removed from

216 the surface waters via scavenging onto particles, especially diatom cells ${ }^{68}$. During GEOVIDE,

217 scavenging onto sinking opal-containing particles was defined as a sink for Al, especially in

218 the Irminger and Labrador basins where diatoms dominate the phytoplankton community ${ }^{69}$.

219 Removal of aluminium via other types of particles (i.e. carbonates, lithogenics, organics, fecal 220 pellets) was not observed in this study, although it cannot be excluded ${ }^{69}$. Using $\mathrm{Al}$ as a 221 lithogenic tracer can thus be questioned, especially for the Irminger and Labrador basins. 222 Another lithogenic tracer that can be used is titanium (Ti) but it is less abundant in the UCC 223 (UCC Ti=0.3\% ${ }^{67}$ ) and its concentrations strongly vary between geological materials. We thus 224 calculated the lithogenic mass (litho) using both tracers:

$$
\text { Litho }(\mu \mathrm{g} / \mathrm{L})=\left(\mathrm{pAl} \times 27 \times 10^{-6}\right) / 0.0804
$$

$$
\text { or Litho }(\mu \mathrm{g} / \mathrm{L})=\left(\mathrm{pTi} \times 47.9 \times 10^{-6}\right) / 0.003
$$

where $p A l$ and $p T i$ are the particulate $\mathrm{Al}$ and Ti concentrations in pmol/L; 0.0804 and 0.003 are the mass fractions of $\mathrm{Al}$ and $\mathrm{Ti}$ in the $\mathrm{UCC}$; and 27 and 47.9 are the molar masses of $\mathrm{Al}$ and $\mathrm{Ti}$ in $\mathrm{g} / \mathrm{mol}$, respectively.

The GEOVIDE transect, and the north Atlantic in general, is characterized by multiple lithogenic sources (atmospheric, sediment or continental inputs) with different geological characteristics. For example, basaltic rocks present close to Iceland and Greenland have a different Ti concentration than gabbro from the Iberian margin, potentially leading to wrong lithogenic estimations. The flux estimates of $\mathrm{MnO}_{2}, \mathrm{Fe}(\mathrm{OH})_{3}$ and $\mathrm{CaCO}_{3}$ are lower, if not negative, when $\mathrm{Ti}$ is used to correct the lithogenic fraction (Fig. S2). We believe that $\mathrm{Ti}$ significantly overestimates the lithogenic fraction when its contribution is low (i.e. at all stations except close to the Iberian margin). In the following, we therefore use Al-calculated fluxes, yet keeping in mind that our mineral fluxes might be overestimated, especially in diatom-rich areas like the Irminger and Labrador basins. 
240 Oxyhydroxides of $\mathrm{Fe}$ and $\mathrm{Mn}$ were calculated by subtracting $\mathrm{Fe}$ and $\mathrm{Mn}$ associated with

241 lithogenic and biogenic materials from total $\mathrm{Fe}$ and $\mathrm{Mn}$. Assuming that Fe oxyhydroxides are

242 ferrihydrite $\left(\mathrm{Fe}(\mathrm{OH})_{3}\right.$ or Fe-oxides hereafter $)$ and $\mathrm{Mn}$ oxyhydroxides are birnessite $\left(\mathrm{MnO}_{2}\right.$ or

$243 \mathrm{Mn}$-oxides hereafter), with formula weights $106.9 \mathrm{~g} \mathrm{Fe}(\mathrm{OH})_{3} / \mathrm{mol} \mathrm{Fe}$ and $86.9 \mathrm{~g} \mathrm{MnO} / \mathrm{mol} \mathrm{Mn}$

$244^{70}$, it is possible to calculate:

245

$$
\mathrm{Fe}(\mathrm{OH})_{3}(\mu \mathrm{g} / \mathrm{L})=[\mathrm{pFe}-(\mathrm{pAl} \times 0.21)-(\mathrm{POC} \times 0.042)] \times 106.9 \times 10^{-3}
$$

246

$$
\mathrm{MnO}_{2}(\mu \mathrm{g} / \mathrm{L})=[\mathrm{pMn}-(\mathrm{pAl} \times 0.00367)-(\mathrm{POC} \times 0.003)] \times 86.9 \times 10^{-3}
$$

247 where $\mathrm{pFe}, p A l$ and $p M n$ are the total particulate concentrations in $\mathrm{nmol} / \mathrm{L}$; POC is the particulate organic carbon concentration in $\mu \mathrm{mol} / \mathrm{L} ; 0.21$ and 0.00367 are respectively the UCC

pFe:pAl and pMn:pAl ratios in $\mathrm{mol} / \mathrm{mol}^{67} ; 0.042$ and 0.003 are respectively the average $\mathrm{Fe}: \mathrm{C}$ et al., $2015^{71}$ ).

Analyses of $\mathrm{pCa}$ and $\mathrm{pNa}$ were made using an inductively coupled plasma atomic emission spectrometer (ICP-AES, ULTIMA 2, Horiba Jobin Yvon). As for pTEs, the accuracy and precision were assessed by analysing the CRM BCR-414 (Table 2). Recovery for pCa reached $80 \%$, keeping in mind that only an indicative value for the CRM reference is available. Replicate analyses were made for 6 samples and differences from the mean value averaged 1.3 and $1.2 \%$ for $\mathrm{pCa}$ and $\mathrm{pNa}$, respectively. As a mineral forming the shells of coccolithophorids, pteropods or foraminifers, we estimate the calcium carbonate $\left(\mathrm{CaCO}_{3}\right)$ concentrations by correcting for sea-salt and lithogenic Ca:

$$
[\mathrm{Ca}]_{\mathrm{CaCO} 3}(\mu \mathrm{g} / \mathrm{L})=\left[\mathrm{pCa}-(\mathrm{Ca}: \mathrm{Na})_{\mathrm{Sw}} \times \mathrm{pNa}-(\mathrm{Ca}: \mathrm{Al})_{\mathrm{UCC}} \times \mathrm{pAl}\right] \times 100.1
$$

where $p C a, p N a$ and $p A l$ are respectively the total particulate calcium, sodium, and aluminium 
seawater ratio ${ }^{72} ;(\mathrm{Ca}: \mathrm{Al})_{U C C}$ is equal to $0.251 \mathrm{~mol} / \mathrm{mol}$ and represents the mean UCC ratio ${ }^{67}$;

267 Following the method of Ragueneau et al. (2005), BSi concentrations were estimated using an alkaline digestion with correction of the lithogenic silica (LSi) ${ }^{73}$. A $25 \mathrm{~mm}$ diameter Nuclepore filter (carrying the LSF) previously counted for Beta activity was inserted in a polymethylpentene centrifuge tube and digested with a $0.2 \mathrm{M} \mathrm{NaOH}$ solution (Merck) at $95^{\circ} \mathrm{C}$ for $1 \mathrm{~h}$. After cooling, the $\mathrm{pH}$ was neutralized by adding $1 \mathrm{M} \mathrm{HCl}$ (Analar Normapur, Merck) and the supernatant was separated from the remaining suspended material by centrifugation. Silicic acid concentrations were determined following an automated acid/molybdate 274 colorimetric method ${ }^{74}$, using an AutoAnalyzer3 Bran\&Luebbe ${ }^{\circledR}$. Dissolved aluminium 275 released during the digestion process was determined by fluorimetric analysis of an Aluminum276 Lumogallion complex (fluorimeter MITHRAS LB 940) ${ }^{75}$. At the end of the digestion, all the 277 BSi is converted into silicic acid, but some lithogenic Si may have dissolved as well, inducing 278 a bias in the BSi concentration. This bias was resolved by applying a second digestion, similar to the first one, allowing the determination of a $\mathrm{Si}: \mathrm{Al}$ ratio exclusively related to the lithogenic material present in the samples. As a mineral forming the shells of diatoms, sponges or radiolarians, we estimate the mass of opal assuming a hydrated form of silica: $\mathrm{SiO}_{2} .\left(0.4 \mathrm{H}_{2} \mathrm{O}\right)$ ${ }^{76}$, or $67.2 \mathrm{~g} \mathrm{opal} / \mathrm{mol} \mathrm{BSi}$ :

$$
\text { Opal }(\mu \mathrm{g} / \mathrm{L})=\left(\left[\mathrm{Si}_{1}\right]-\left[\mathrm{Al}_{1}\right] \times(\mathrm{Si}: \mathrm{Al})_{2}\right) \times 67.2
$$
where $\left[\mathrm{Si}_{1}\right]$ and $\left[\mathrm{Al}_{1}\right]$ are the concentrations of silicic acid and aluminium determined during the first digestion in $\mu \mathrm{mol} / \mathrm{L} ;(S i: A l)_{2}$ is the ratio of the concentrations of silicic acid and 
Trace element and mineral (lithogenics, Fe- and Mn-oxides, $\mathrm{CaCO}_{3}$, opal) export fluxes were 290 determined using the ${ }^{234} \mathrm{Th}$-based approach by multiplying the TE: ${ }^{234} \mathrm{Th}$ or mineral: ${ }^{234} \mathrm{Th}$ ratio of sinking particles with the total ${ }^{234}$ Th export flux ${ }^{60}$, both determined at the same depth:

$$
\text { Component export flux }=\left(\text { component: }{ }^{.34} \mathrm{Th}\right) \text { particulate } \times{ }^{234} \mathrm{Th} \text { flux }
$$

293

294

295

296

297

298

299

300

301

302

303

304

305

306

with component being either a TE or a mineral phase.

As we do not have $\mathrm{p}^{234} \mathrm{Th}$ activities available for the SSF, we only consider the component: ${ }^{234} \mathrm{Th}$ ratios from the LSF in this study. Large particles $(>53 \mu \mathrm{m})$ are generally assumed to represent the sinking particulate matter and are thus responsible for the particulate export flux ${ }^{77-79}$. Using the component: ${ }^{234}$ Th ratios from the LSF to calculate export fluxes is the most common approach ${ }^{36,80-83}$. However, recent studies have shown that the SSF could also contribute to the export flux of particulate carbon or nitrogen in oligotrophic regions ${ }^{20,21,84}$. Black et al. (2019) reported no significant differences in SSF and LSF pP. ${ }^{234} \mathrm{Th}, \mathrm{pCo}:{ }^{234} \mathrm{Th}$ and $\mathrm{pCd}:{ }^{234} \mathrm{Th}$ ratios contrasting with the higher $\mathrm{pMn}:{ }^{234} \mathrm{Th}$ ratios in the LSF compared to the SSF, leading to a greater contribution of the LSF to the total $\mathrm{pMn}$ flux ${ }^{36}$.

Vertical export fluxes were determined at the depth where total ${ }^{234} \mathrm{Th}$ is back to secular equilibrium with ${ }^{238} \mathrm{U}$ (equilibrium depth or Eq hereafter; Table 3). The ${ }^{234} \mathrm{Th}$ export at Eq represents the fully-integrated depletion of total ${ }^{234} \mathrm{Th}$ in the upper waters ${ }^{60}$. To collect particles, three to four depths were sampled per ISP in the upper 150m while in that same depth range, Niskin casts sampled nine depths. Because of this difference of depth resolution we use an interpolation method to estimate the component: ${ }^{234} \mathrm{Th}$ ratios for the layer between surface and Eq. The depth-weighted average (DWA) was chosen as this method yields similar TE: ${ }^{234} \mathrm{Th}$ or mineral: ${ }^{234} \mathrm{Th}$ ratios than those obtained from sediment traps ${ }^{31}$ (DWA; element: ${ }^{234} \mathrm{Th}=\left[\Sigma\left(\right.\right.$ element $\left.\left._{\mathbf{i}} \times \mathrm{Z}_{\mathbf{i}}\right) / \Sigma\left(\mathrm{Z}_{\mathbf{i}}\right)\right] /\left[\Sigma\left({ }^{234} \mathrm{Th}_{\mathbf{i}} \times \mathrm{Z}_{\mathbf{i}}\right) / \Sigma\left(\mathrm{Z}_{\mathbf{i}}\right)\right]$ where $\mathrm{Z}_{\mathbf{i}}$ are the depth intervals 
sampled above Eq). Uncertainties of ratios and fluxes were obtained using error propagation

313 law.

\subsection{Residence times}

316 We also investigated the total residence time $(\tau)$ of TEs, which was obtained by dividing the

317 TE inventory within a specific reservoir by the TE flux into or out of this reservoir, thereby 318 assuming steady state with removal rates equalling supply rates (Equation 8). We focused on 319 total (dissolved+particulate) residence time $\left(\tau_{\text {total }}\right)$ within the surface-Eq layer depth (Table 5) 320 and we considered the particulate export flux as the main output flux of TE from the upper ocean. Advective and diffusive circulation fluxes are generally slow processes compared to the vertical export processes and were neglected here ${ }^{25,35}$. However these processes have been shown to have impact, though limited, on measured ${ }^{234}$ Th export fluxes along the GEOVIDE

324 transect ${ }^{60}$, and therefore $\tau_{\text {total }}$ of TE might represent a higher end estimation in the present 325 study.

$$
\tau=\frac{\text { total TE inventory }}{\text { particulate TE export flux }}
$$

327 with the particulate TE export flux in $\mu \mathrm{g} / \mathrm{m}^{2} / \mathrm{d}$ at Eq (from this study), and the total TE inventory in $\mu \mathrm{g} / \mathrm{m}^{2}$ obtained by summing the particulate $(>0.45 \mu \mathrm{m})$ and dissolved $(<0.45 \mu \mathrm{m})$

329 TE phases, both being collected using GO-FLO bottles (Planquette et al., personal 330 communication, 2019 and ${ }^{65,69,85}$ ). Inventories were calculated using a depth-weighted integration in the surface-Eq layer. Uncertainties in Table 5 represent the highest deviation between the residence time obtained at $\mathrm{Eq}$ and those obtained at $\mathrm{Eq}+20 \mathrm{~m}$ or Eq-20m $(20 \mathrm{~m}$ being the average error on the determination of the Eq depth). 


\section{RESULTS}

336

337

338

339

340

341

342

343

344

345

346

347

348

349

350

351

352

353

354

355

356

357

358

359

3.1. Activities of $\mathrm{p}^{234} \mathrm{Th}$ and concentrations of TEs, lithogenic, authigenic and biogenic phases in the large size fraction $(>53 \mu \mathrm{m})$

Distributions of $\mathrm{p}^{234} \mathrm{Th}$ vary along the transect (Fig. S3, Table S1) with the lowest activities being determined in the Iberian basin (as low as $0.006 \mathrm{dpm} / \mathrm{L}$ in subsurface of Station \#1) and the highest in surface waters of the Irminger basin (up to $0.2 \mathrm{dpm} / \mathrm{L}$ in surface of Station \#51). In general, activities are high in surface and decrease with depth but some subsurface maxima also occur, such as at 100m of Station \#64 where activities reach $0.16 \mathrm{dpm} / \mathrm{L}$.

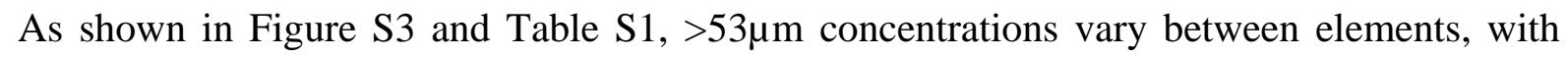
values ranging from $10^{-6}$ to $10^{1} \mathrm{nmol} / \mathrm{L}$ in the suite of $\mathrm{Cd}, \mathrm{Co}<\mathrm{Cu}, \mathrm{Mn}, \mathrm{Ni}, \mathrm{Ti}, \mathrm{Zn}<\mathrm{Fe}<\mathrm{Al}$, P. Similarly to $\mathrm{p}^{234} \mathrm{Th}$ activities, concentrations and distributions also vary significantly for each pTE along the transect, like those of the lithogenic, authigenic and biogenic phases.

Concentrations of $\mathrm{pAl}$ or lithogenic material, like that of $\mathrm{pFe}$ and $\mathrm{pTi}$, which are known to be associated with lithogenic material, generally increase with depth and are highest at proximity of the Iberian margin (Station \#1) reaching up to $15 \mathrm{nmol} / \mathrm{L}, 5.2 \mu \mathrm{g} / \mathrm{L}, 3.2 \mathrm{nmol} / \mathrm{L}$ and 0.2 $\mathrm{nmol} / \mathrm{L}$ at 550m respectively. Similarly, $\mathrm{pMn}$ and $\mathrm{pZn}$ show maximal concentrations over the transect at 550m at Station \#1 (0.05 and $0.9 \mathrm{nmol} / \mathrm{L}$, respectively) though high concentrations are also observed at 100m at Station \#64 (0.03 and $0.07 \mathrm{nmol} / \mathrm{L}$, respectively) like pCd, pCu, $\mathrm{pNi}$ and $\mathrm{pV}(7.1 \mathrm{pmol} / \mathrm{L}, 0.04,0.02$ and $0.05 \mathrm{nmol} / \mathrm{L}$, respectively; Table S1). Lithogenic material is also strongly enriched at 100m at Station \#64 and 200m at Station \#77 (> $0.8 \mu \mathrm{g} / \mathrm{L})$. Except for these stations located closer to margins, concentrations of lithogenic material are low, averaging $0.2 \mu \mathrm{g} / \mathrm{L}$.

Particulate $\mathrm{Cd}$, Co and $\mathrm{P}$ are characterized by biogenic distributions, with higher concentrations in surface waters, especially in the productive west European basin (Stations \#21 and \#26). Other pTEs are characterized by high surface concentrations such as $\mathrm{pV}$ and $\mathrm{pZn}$ in the 

basins. These coincide with elevated concentrations of both opal and $\mathrm{CaCO}_{3}$ in the upper $100 \mathrm{~m}$, where they are produced: highest $\mathrm{CaCO}_{3}$ concentrations mainly occur within the west European and Icelandic basins (up to $14 \mu \mathrm{g} / \mathrm{L}$ ) whereas highest opal concentrations occur within the west European, Irminger and Labrador basins (up to $95 \mu \mathrm{g} / \mathrm{L}$ ). In general, both biogenic phases display nutrient-like profiles with highest concentrations in surface waters, but deeper $\mathrm{CaCO}_{3}$ maxima occur at Station \#32 at 100m, Station \#38 at 60m and Station \#64 at 100m while deeper opal maxima occur at Stations \#38 and \#64 at 100m.

Slight increase of $\mathrm{pFe}, \mathrm{pMn}, \mathrm{pCd}, \mathrm{pCo}, \mathrm{pCu}, \mathrm{pNi}$ and $\mathrm{pZn}$ concentrations are observed in subsurface, such as at $60 \mathrm{~m}$ and $100 \mathrm{~m}$ at Station \#64, in the upper $200 \mathrm{~m}$ at Stations \#32 and \#38 and below 100m at Station \#26. Iron and manganese oxide contents follow similar trends. Both authigenic minerals are obtained after correction of the contribution of lithogenic and biogenic fractions, and therefore show low concentrations along the section, with exceptions at the depths cited just above. At $60 \mathrm{~m}$ at Station $\# 64, \mathrm{Fe}(\mathrm{OH})_{3}$ and $\mathrm{MnO}_{2}$ concentrations reach 0.16 and $0.003 \mu \mathrm{g} / \mathrm{L}$ respectively, but are also relatively high at $100 \mathrm{~m}$, coinciding with elevated lithogenic contents $(0.05$ and $0.002 \mu \mathrm{g} / \mathrm{L}$ respectively $)$. High $\mathrm{Fe}(\mathrm{OH})_{3}$ concentrations are also observed in the upper $200 \mathrm{~m}$ of the Icelandic basin (from 0.01 to $0.03 \mu \mathrm{g} / \mathrm{L}$ at Stations \#32 and \#38) while high $\mathrm{MnO}_{2}$ concentrations are seen below $100 \mathrm{~m}$ of Station \#26 (up to $0.002 \mu \mathrm{g} / \mathrm{L}$ ). Overall, our $>53 \mu \mathrm{m}$ pTE concentrations are comparable with those of the world ocean literature 31,36,86. If we compare more closely to data from the GA03 cruise, which also took place in the 380 North Atlantic (GEOTRACES IDP2017 ${ }^{87}$ ), our concentrations of pP are slightly higher, reaching $24 \mathrm{nmol} / \mathrm{L}$ during GEOVIDE (4.7 nmol/L during GA03), likely because of the higher productivity observed in the subpolar compared to the subtropical North Atlantic. On the other hand, both cruises have similar order of magnitudes in the whole water column for pCd (up to 
GEOVIDE and GA03, respectively), $\mathrm{pCu}$ (up to 36 and $28 \mathrm{pmol} / \mathrm{L}$ for GEOVIDE and GA03, $(0.1-15 \mathrm{nmol} / \mathrm{L}), \mathrm{pFe}(0.02-3.2 \mathrm{nmol} / \mathrm{L})$ and $\mathrm{pTi}(0.004-0.2 \mathrm{nmol} / \mathrm{L})$ are lower than those observed during GA03 (0.1-98, 0.04-25 and 0.004-3.6 nmol/L, respectively $\left.{ }^{44}\right)$. This might be due to the fact that both cruises took place at different latitudes, with the GA03 transect located in the dust rich region of the Atlantic.

393

3.2. Particulate TE: ${ }^{234} \mathrm{Th}$ and mineral: ${ }^{234} \mathrm{Th}$ ratios in the large size fraction $(>53 \mu \mathrm{m})$

Magnitudes of ratios differ among elements (pCd: ${ }^{234} \mathrm{Th}, \mathrm{pCo}:{ }^{234} \mathrm{Th}<\mathrm{pCu}:{ }^{234} \mathrm{Th}, \mathrm{pNi}:{ }^{234} \mathrm{Th}$, 396 pV: $\left.{ }^{234} \mathrm{Th}<\mathrm{pMn}:{ }^{234} \mathrm{Th}, \mathrm{pTi}:{ }^{234} \mathrm{Th}, \mathrm{pZn}:{ }^{234} \mathrm{Th}<\mathrm{pFe}:{ }^{.234} \mathrm{Th}<\mathrm{pAl}:{ }^{234} \mathrm{Th}, \mathrm{pP}:{ }^{234} \mathrm{Th}\right)$ and vary between basins as described below. Profiles of pTE: ${ }^{234} \mathrm{Th}$ and mineral: ${ }^{234} \mathrm{Th}$ ratios in the $>53$ $\mu \mathrm{m}$ fraction generally follow those observed for the concentrations (Fig. S4).

399 Ratios of pAl: ${ }^{234} \mathrm{Th}(1204 \mathrm{nmol} / \mathrm{dpm})$ or lithogenic: ${ }^{234} \mathrm{Th}(404 \mu \mathrm{g} / \mathrm{dpm})$ reach highest values at $250 \mathrm{~m}$ at Station \#1. Similarly, highest pCo: ${ }^{.34} \mathrm{Th}(0.08 \mathrm{nmol} / \mathrm{dpm}), \mathrm{pCu}:{ }^{234} \mathrm{Th}(0.4 \mathrm{nmol} / \mathrm{dpm})$, pFe: ${ }^{234}$ Th $(245 \mathrm{nmol} / \mathrm{dpm}), \mathrm{pMn}:{ }^{234} \mathrm{Th}(4 \mathrm{nmol} / \mathrm{dpm})$ and pTi: ${ }^{234} \mathrm{Th}(18 \mathrm{nmol} / \mathrm{dpm})$ occur at $250 \mathrm{~m}$ at Station \#1. Lithogenic: ${ }^{234} \mathrm{Th}$ ratios generally increase with depth but also show elevated values at the surface (15-30m) of Stations \#1, \#21 and \#32.

404 High $\mathrm{pP}:{ }^{234} \mathrm{Th}$ and $\mathrm{pV}:{ }^{234} \mathrm{Th}$ ratios are observed in the upper $100 \mathrm{~m}$ of the Irminger and Labrador 405 basins (reaching 121 and $0.9 \mathrm{nmol} / \mathrm{dpm}$, respectively), like high opal: ${ }^{234} \mathrm{Th}$ ratios $(750 \mu \mathrm{g} / \mathrm{dpm}$ at $30 \mathrm{~m}$ of Station \#69). In the west European and Icelandic basins, ratios of $\mathrm{pCd} \cdot{ }^{234} \mathrm{Th}$, pCo: ${ }^{234} \mathrm{Th}, \mathrm{pCu}:{ }^{234} \mathrm{Th}, \mathrm{pFe}:{ }^{234} \mathrm{Th}, \mathrm{pNi}:{ }^{234} \mathrm{Th}, \mathrm{pP}:{ }^{234} \mathrm{Th}$ and $\mathrm{pZn}:{ }^{.234} \mathrm{Th}$ increase towards the surface, similarly to $\mathrm{CaCO}_{3}:{ }^{234} \mathrm{Th}$ (reaching $271 \mu \mathrm{g} / \mathrm{dpm}$ at $109 \mathrm{~m}$ at Station \#38). 
Some exceptions are observed at 60m at Station \#64 and in the Icelandic basin, especially at $200 \mathrm{~m}$ at Station \#32, where we determined high ratios of $\mathrm{pCo}:{ }^{234} \mathrm{Th}(0.01$ and $0.04 \mathrm{nmol} / \mathrm{dpm}$

411 at Stations \#64 and \#32, respectively), pCu: ${ }^{234} \mathrm{Th}\left(0.17 \mathrm{nmol} / \mathrm{dpm}\right.$ at Station \#32), pNi: ${ }^{234} \mathrm{Th}$

412 (0.14 and $1.04 \mathrm{nmol} / \mathrm{dpm}$ at Stations \#64 and \#32, respectively) and pZn: ${ }^{234} \mathrm{Th}$ (from 1.5 to 5.2 $413 \mathrm{nmol} / \mathrm{dpm}$ in the upper $60 \mathrm{~m}$ of the Icelandic basin). These high values correspond to the highest $414 \mathrm{Fe}(\mathrm{OH})_{3}:{ }^{234} \mathrm{Th}$ ratios $(6.5 \mu \mathrm{g} / \mathrm{dpm}$ at $60 \mathrm{~m}$ at Station \#64, and 1.04-2.25 $\mu \mathrm{g} / \mathrm{dpm}$ in the upper $415200 \mathrm{~m}$ at Station \#32). The highest $\mathrm{MnO}_{2}:{ }^{234} \mathrm{Th}$ ratios are also observed at $60 \mathrm{~m}$ at Station \#64, 416 and at $153 \mathrm{~m}$ at Station \#26, coinciding with a slight increase of the $\mathrm{pZn}:{ }^{234}$ Th ratio (1.2 $417 \mathrm{nmol} / \mathrm{dpm})$.

\subsection{Export fluxes}

420

Export fluxes at Eq (between 40 and 110m) significantly vary between elements and between basins (Table 3, Fig. 2). The most striking results are the maximal flux of pAl or lithogenic material $\left(9207 \mu \mathrm{g} / \mathrm{m}^{2} / \mathrm{d}\right.$ and $115 \mathrm{mg} / \mathrm{m}^{2} / \mathrm{d}$, respectively) and of some pTEs in vicinity of the Iberian margin (Station \#1), with extreme values for $\mathrm{pCo}, \mathrm{pFe}, \mathrm{pMn}, \mathrm{pP}$ and pTi $(3.6,3912$, 55,8141 and $340 \mu \mathrm{g} / \mathrm{m}^{2} / \mathrm{d}$, respectively). Such high fluxes evidence particulate inputs from the Iberian margin, leading to the export of pTE out of the surface layer.

The highest $\mathrm{CaCO}_{3}$ export fluxes occur within the west European and Icelandic basins, where blooms of coccolithophorids were observed during GEOVIDE ${ }^{62}$. There, we also observe high fluxes of $\mathrm{pCd}, \mathrm{pCu}, \mathrm{pNi}$ or $\mathrm{pP}$, which at Station \#21 reach values of $11,18,84$ and 4648 $\mu \mathrm{g} / \mathrm{m}^{2} / \mathrm{d}$, respectively. Opal fluxes are the highest in the Irminger and Labrador basins, where diatom blooms were declining during GEOVIDE ${ }^{60}\left(568 \mathrm{mg} / \mathrm{m}^{2} / \mathrm{d}\right.$ at Station \#64). Surprisingly, the settling of diatoms in these basins is characterized by low pTE export fluxes.

432 High $\mathrm{Fe}(\mathrm{OH})_{3}$ export flux is observed in the Icelandic basin (Station 32) and in the western 433 Labrador basin (Station \#64). At Station \#32, the high $\mathrm{Fe}(\mathrm{OH}) 3$ flux $\left(1.3 \mathrm{mg} / \mathrm{m}^{2} / \mathrm{d}\right)$ goes with 
high fluxes of pAl, pCd, pCo, pCu, pFe, pMn, pNi, pP, pV and pZn $(469,5.1,2.7,10,931,13$, 33, 4145, 1.7 and $396 \mu \mathrm{g} / \mathrm{m}^{2} / \mathrm{d}$, respectively). Export fluxes of $\mathrm{MnO}_{2}$ are small compared to other mineral fluxes $\left(0.007 \mathrm{mg} / \mathrm{m}^{2} / \mathrm{d}\right.$ compared to $0.36 \mathrm{mg} / \mathrm{m}^{2} / \mathrm{d}$ for $\mathrm{Fe}(\mathrm{OH})_{3}$ on average $)$. In general, high fluxes of $\mathrm{MnO}_{2}$ and $\mathrm{Fe}(\mathrm{OH})_{3}$ coincide but $\mathrm{MnO}_{2}$ fluxes are particularly high in the west European (Station \#26) and Irminger (Station \#44) basins where we can observe a slight increase of $\mathrm{pCo}, \mathrm{pMn}$ and $\mathrm{pV}$ fluxes (reaching $0.4,9.3$ and $0.4 \mu \mathrm{g} / \mathrm{m}^{2} / \mathrm{d}$, respectively, at Station \#26).

441 Particulate TE export fluxes determined using the ${ }^{234} \mathrm{Th}$ approach are still scarce in the

442 literature. Comparing different biogeochemical areas is difficult because of differences in 443 sampling periods (and different productivities), export depths (surface versus deep or Eq depth 444 versus fixed depth) or locations (shelf versus open-ocean). However, the overall ranges of pTE export fluxes between GEOVIDE and the literature are comparable. The pFe export flux at proximity of the Iberian margin $\left(3912 \mu \mathrm{g} / \mathrm{m}^{2} / \mathrm{d}\right)$ is by far the highest observed along the GEOVIDE transect but is still lower than fluxes determined on the Scotian shelf $\left(7874 \mu \mathrm{g} / \mathrm{m}^{2} / \mathrm{d}\right.$ $\left.{ }^{88}\right)$, or close to the Crozet island $\left(8098 \mu \mathrm{g} / \mathrm{m}^{2} / \mathrm{d}^{32}\right)$, where lithogenic inputs are even higher. 449 Conversely, the lower pAl export fluxes in the Labrador Sea $\left(67-281 \mu \mathrm{g} / \mathrm{m}^{2} / \mathrm{d}\right.$ at GEOVIDE 450 Stations \#64, \#69 and \#77 and 432-594 $\mu \mathrm{g} / \mathrm{m}^{2} / \mathrm{d}$ in $2005^{34}$ ) indicate lower lithogenic inputs, 451 which seem to drive lower pFe export fluxes (41-501 $\mu \mathrm{g} / \mathrm{m}^{2} / \mathrm{d}$ at GEOVIDE Stations \#64, \#69 and \#77 and 480-614 $\mu \mathrm{g} / \mathrm{m}^{2} / \mathrm{d}$ in $2005^{34}$ ). Even though GEOVIDE took place during the spring 453 bloom, export of $\mathrm{pP}\left(266-8141 \mu \mathrm{g} / \mathrm{m}^{2} / \mathrm{d}\right)$ is lower than observed along the GP16 transect, from 454 the Peruvian shelf to the subtropical Pacific gyre $\left(254-27876 \mu \mathrm{g} / \mathrm{m}^{2} / \mathrm{d}^{36}\right)$ likely due to high 455 productivities and high biogenic exports induced by the coastal upwelling there. Similarly, particulate organic carbon (POC) export reaches $960 \mathrm{mg} / \mathrm{m}^{2} / \mathrm{d}$ during GP16 compared to 139 $\mathrm{mg} / \mathrm{m}^{2} / \mathrm{d}$ during GEOVIDE ${ }^{83}$. For that same Pacific ocean area, Black et al. (2019) ${ }^{36}$ reports 458 similar pCo fluxes $\left(0.1-4 \mu \mathrm{g} / \mathrm{m}^{2} / \mathrm{d}\right)$ but much higher $\mathrm{pCd}\left(0.2-112 \mu \mathrm{g} / \mathrm{m}^{2} / \mathrm{d}\right)$ and $\mathrm{pMn}$ export 
459 fluxes (6-549 $\left.\mu \mathrm{g} / \mathrm{m}^{2} / \mathrm{d}\right)$ compared to fluxes in the North Atlantic reaching up to $4 \mu \mathrm{g} \mathrm{pCo} / \mathrm{m}^{2} / \mathrm{d}$, $46011 \mu \mathrm{g} \mathrm{pCd} / \mathrm{m}^{2} / \mathrm{d}, 55 \mu \mathrm{g} \mathrm{pMn} / \mathrm{m}^{2} / \mathrm{d}$ for the present GEOVIDE section and $3 \mu \mathrm{g} \mathrm{pCd} / \mathrm{m}^{2} / \mathrm{d}$ for the

461 Scotian shelf area ${ }^{88}$. Finally, Smith et al. (2014) ${ }^{88}$ reports similar pCu export fluxes for the

462 Scotian shelf $\left(1-22 \mu \mathrm{g} / \mathrm{m}^{2} / \mathrm{d}\right)$ compared to those observed for the GEOVIDE transect (1-16 $\left.463 \mu \mathrm{g} / \mathrm{m}^{2} / \mathrm{d}\right)$.

464

465

3.4. Residence times

466 Along the GEOVIDE transect, TE inventories and exports, and consequently residence times, 467 vary considerably (Table 5). Trace element residence times in the surface-Eq depth layer range 468 from 2 to 13297 days: $\mathrm{Al}(4 \pm 0.2-106 \pm 3$ days $)$, Fe $(2 \pm 0.1-147 \pm 5$ days $)<\mathrm{Mn}(89 \pm 25-$ $626 \pm 80$ days $), \operatorname{Zn}(4 \pm 0.4-582 \pm 18$ days $)<\operatorname{Co}(64 \pm 3-3427 \pm 209$ days $), \mathrm{Cu}(236 \pm 11-3646 \pm 698$

470 days $)<\mathrm{Ni}(339 \pm 15-13297 \pm 407$ days $)$.

471 High particulate and dissolved inventories, high export fluxes and short $\tau_{\text {total }}$ are observed at 472 Station \#1, close to the Iberian margin, for all TEs. There, we observe the shortest residence 473 times for $\mathrm{Al}\left(\tau_{\text {total }}=4\right.$ days $), \mathrm{Co}\left(\tau_{\text {total }}=64\right.$ days $), \mathrm{Cu}\left(\tau_{\text {total }}=236\right.$ days $)$ and $\mathrm{Fe}\left(\tau_{\text {total }}=2\right.$ days $)$.

474 However, $\tau_{\text {total }}$ values for $\mathrm{Mn}, \mathrm{Zn}$ and $\mathrm{Ni}$ at Station \#1 are not the shortest ones along the 475 transect.

476 The Icelandic and western European basins are also characterized by short element residence 477 times. For example, the residence time for Fe is only 3 days (at Stations \#32 and \#38) and Ni 478 and $\mathrm{Zn}$ residence times are shorter there $\left(\mathrm{Ni}: \tau_{\text {total }}=339\right.$ days at Station \#21; $\mathrm{Zn}: \tau_{\text {total }}=4$ days at 479 Station \#32) than near the Iberian margin. A major difference with the Iberian margin is the 480 generally lower surface water particulate and dissolved inventories for most TEs in the 481 Icelandic and west European basins (Table 5).

482 Finally, $\tau_{\text {total }}$ for all TEs are much longer, generally of the order of years $(5,9,7,36$ and 2 years 483 for $\mathrm{Co}, \mathrm{Cu}, \mathrm{Mn}, \mathrm{Ni}$ and $\mathrm{Zn}$ respectively) within the Labrador and Irminger basins, while they 
are less than a year or even only a few days, within the west European/Icelandic and Iberian basins. For example, Fe residence times average 47 days within the Labrador and Irminger

486 basins compared to an average of 10 days for the west European/Icelandic basins and 2 days for Station \#1 at the Iberian margin. For all TEs, except Co, $\tau_{\text {total }}$ is maximal at Station \#77 in the Labrador Sea. For Co, the maximum $\tau_{\text {total }}$ is reached at Station \#64, also in the Labrador Sea.

\section{DISCUSSION}

Since particulate ${ }^{234}$ Th was not analysed on filters dedicated to trace metal analyses in the SSF, element: ${ }^{234} \mathrm{Th}$ ratios could only be determined for the LSF, which is assumed to be representative of sinking particles ${ }^{89}$. To our knowledge, this assumption has been used in all studies dedicated to TE export fluxes and using ISP ${ }^{31,32,34-36}$. We are aware though, that small particles may contribute to the TE export.

\subsection{Statistical analyses}

In order to gain more insight about the vector phases carrying each elemental flux, we examined the Spearman rank correlation coefficients between TE and mineral exports (XLStat software; Table 4). The analysis was conducted on log-transformed export fluxes to ensure that input variables are more normally distributed and to reduce the influence of extreme values. The influence of lithogenic materials on the pTE export fluxes is highlighted by the significant correlations, especially for $\mathrm{pCu}, \mathrm{pFe}$ and $\mathrm{pZn}$ ( $\mathrm{p}$-value $<0.05$ and $\mathrm{R} \geq 0.9$; Table 4). At a lesser extent but still significantly, $\mathrm{pCd}, \mathrm{pCo}, \mathrm{pNi}$ and $\mathrm{pTi}$ export fluxes are also correlated to lithogenic fluxes ( $\mathrm{p}$-value $<0.05$ and $\mathrm{R} \geq 0.6$; Table 4). Biogenic (opal and $\mathrm{CaCO}_{3}$ ) and oxide $\left(\mathrm{Fe}(\mathrm{OH})_{3}\right.$ and $\left.\mathrm{MnO}_{2}\right)$ phases do not show any significant correlations with the pTEs, likely due to the significance of lithogenic particles in controlling TE fluxes in the North Atlantic (Table 
4). In order to disentangle the roles of the biogenic and oxide phases on pTE fluxes, we used a

510 principal component analysis (PCA; XLStat software) considering excess pTE exports (ie. pTE

511 export fluxes corrected from the lithogenic fraction; Fig. 3). Recent studies have applied a PCA

512 approach for large datasets of element concentrations, including small and large particle size

513 fractions ${ }^{19,44,65,90}$, but we only consider here export fluxes at the Eq depth based on the large

514 particle size fraction (with GEOVIDE particulate concentrations being reported and discussed

515 elsewhere; Planquette et al., personal communication, 2019 and Gourain et al., $2019^{65}$ ). To

516 only comment on the distribution of the pTEs, neither mineral exports nor chemical variables

517 are included in the PCA. The PCA has been conducted after a Varimax rotation which appeared

518 to clarify the relationship among variables by better capturing known dynamics of the water

519 column ${ }^{19,91}$. This analysis is also conducted on log-transformed export fluxes to limit the 520 influence of extreme values and to ensure a more normal distribution of the variables ${ }^{19,92}$. We

521 identified four principal components that together explain $95 \%$ of the total dataset variance

522 (Fig. 3).

523 The first principal component (33\% of the total variance) likely describes the biological

524 influence as it explains 84 and $81 \%$ of the excess pCd and pP flux variances, respectively. This component also explains 55\% of the excess pCu flux and between 9 and $17 \%$ of the excess pCo, pNi and pZn fluxes. In Table 4, pP appears to be correlated with most pTEs (p-value < 0.05 and $\mathrm{R}>0.65$ for $\mathrm{pCd}, \mathrm{pCo}, \mathrm{pCu}$ and $\mathrm{pMn}$ fluxes and $\mathrm{R}>0.45$ for $\mathrm{pAl}, \mathrm{pNi}$ and $\mathrm{pZn}$ ). To 528 investigate the biological influence on pTE fluxes, we also examined their correlations with

$529 \mathrm{POC}, \mathrm{CaCO}_{3}$ and opal. No significant correlation was observed.

530 The second component (30\% of the total variance) explains $74 \%$ of both excess pCo and pZn

531 fluxes variances and also explains, at a lesser extent, the export fluxes of other pTEs (12-41\% 532 of excess $\mathrm{pCd}, \mathrm{pCu}, \mathrm{pNi}$ variances and $6 \%$ of excess $\mathrm{pP}$ variance). Interestingly, Ohnemus et 533 al. (2019) also found a factor strongly driven by pCo abundances, with additional - smaller - 
contributions for other pTEs. They related this factor to a secondary (heterotrophic) biomass phase ${ }^{19}$.

536 The third principal component (19\% of the total variance) is strongly indicative of authigenic

537 Fe oxides, as it explains $89 \%$ of the variability of excess pFe fluxes. In addition, this third 538 component also explains $21 \%$ of the variance of excess pNi flux and between 4 and $9 \%$ of the 539 variances of excess $\mathrm{pCo}, \mathrm{pCu}, \mathrm{pMn}, \mathrm{pP}$ and $\mathrm{pZn}$ fluxes, reflecting the scavenging of these TEs onto this authigenic phase ${ }^{93}$. Furthermore, the correlation analysis highlights links between

541 authigenic $\mathrm{Fe}$ oxide and $\mathrm{Mn}$ oxide fluxes $(\mathrm{R}=0.77), \mathrm{CaCO}_{3}$ fluxes $(\mathrm{R}=0.63)$ and pTEs, 542 especially pNi, pCu and pZn fluxes $(\mathrm{R}=0.30-0.46$; Table 4).

543 Finally, the fourth component (14\% of the total variance) probably describes the influence of

544 authigenic Mn oxides as it explains $90 \%$ of the variance of excess pMn fluxes. It is associated 545 at 6-8\% with excess $\mathrm{pFe}$ and $\mathrm{pNi}$ fluxes, and at $1-3 \%$ with $\mathrm{pCd}, \mathrm{pCo}, \mathrm{pCu}$ and $\mathrm{pP}$ fluxes.

\subsection{Lithogenic contribution to fluxes}

548 Lithogenic particles play a central role in the North Atlantic (Table 4). They can originate from different sources such as atmospheric deposition, glacial meltwater, advection of sedimentenriched water masses or lateral mixing with shallow coastal waters under continental influence. The importance of lithogenic sources is particularly clear for Station \#1, suggesting an input from the Iberian margin (Fig. 2) in agreement with the literature ${ }^{44,59}$. There, we determined the highest fluxes for lithogenic material and some pTEs, which were accompanied by pTE:pAl ratios close to $\mathrm{UCC}^{67}$ (Fig. 4; Fig. S5). This is especially the case for pFe and pMn for which the respective ratios show only 2 and $20 \%$ offset relative to UCC ratios (Fig. 4). For other pTEs, these ratios are slightly greater than for UCC, pointing to the presence of another

557 driver of export fluxes. Such TE enrichments relative to the UCC have also been reported in 558 the estuary of the Tagus river ${ }^{94}$ for which the plume has been shown to reach Station \#1 ${ }^{69,85}$. 
This river is known to receive effluents from agricultural, industrial and urban sources and thus represents an important discharge of dissolved and particulate TE concentrations to the estuary 95-98. The slightly higher pTE:pAl ratios compared to UCC may indicate that fluxes at Station \#1 are under anthropogenic influence via the discharge from the Tagus estuary.

563 Stations at proximity of the Greenland and Newfoundland margins are also characterized by some higher pTE:pAl ratios (i.e., pCd:pAl or pCu:pAl; Fig. 4), implying additional processes in the export of these pTEs. Although lithogenic particles settle quickly through the water column, they can also adsorb elements onto their surfaces ${ }^{44,99,100}$. Such scavenging processes could explain the higher pTE:pAl ratios. Interestingly, the Greenland and Newfoundland margin stations are characterized by much lower lithogenic and pTE flux intensities compared to the Iberian margin (Fig. 2), suggesting that lithogenic material is not similarly released at all margins. Such differences can depend on the morphology of the margin and on the hydrodynamical forcing, providing (or not) significant amounts of lithogenic particles and

572 leading (or not) to the formation of nepheloid layers ${ }^{101}$. Indeed, relatively high lithogenic 573 export fluxes are also observed at open-ocean stations beyond the Iberian margin (up to Station 574 \#32). The Iberian margin is known to be an efficient exporter of particulate matter to the open and deep sea ${ }^{102,103}$ and during GEOVIDE, high proportions of lithogenic particulate rare earth 576 elements ${ }^{101}$ and $\mathrm{pFe}^{65}$ were observed up to $1700 \mathrm{~km}$ far from the Iberian margin. These 577 enrichments were attributed to the presence of intermediate nepheloid layers transported along 578 the isopycnals, which then likely drive pTEs fluxes to the deep ocean. To a lesser extent, 579 lithogenic particles were also transported to the west of the Greenland margin ${ }^{65}$, in line with the moderate lithogenic export fluxes observed at Station \#64, in the eastern Labrador basin.

581 Conversely, lithogenic particles do not seem to spread off the Newfoundland margin, thereby explaining the lower lithogenic export fluxes at Station \#77. 
High fluxes of Mn- and Fe-oxides were determined at some stations close to margins, also under lithogenic influence (i.e. Station \#64), and at open-ocean stations, which are not necessarily characterized by high particulate lithogenic exports. For example, Station \#26 presents one of the lowest lithogenic and $\mathrm{Fe}(\mathrm{OH})_{3}$ fluxes, while $\mathrm{MnO}_{2}$ fluxes are among the highest at this station. This decoupling between high pMn and low pAl fluxes has already been observed and was attributed to a distant shelf source of lithogenic particles ${ }^{30}$. Indeed, nepheloid layers sourced at the shelves lose particles by gravitational settling during lateral advection, but in the case of $\mathrm{Mn}$, it has been shown that dissolved Mn, remobilized from the shelf, oxidizes very slowly, enriching the particulate phase during transport ${ }^{104}$. Long distance transport inducing a subsurface pMn maximum was observed off the Kuril/Kamchatka margin, in the western subarctic Pacific ${ }^{18}$. High pMn concentrations and fluxes at Station \#26 could thus have originated from authigenically precipitated Mn during its transport from the American coasts, via the North Atlantic Current (NAC, Fig. 1). The distance between Station \#26 and North Carolina coasts (USA) is around $4500 \mathrm{~km}$, which roughly corresponds to the distance of $4220 \mathrm{~km}$ calculated by multiplying a NAC velocity of $0.4 \mathrm{~m} / \mathrm{s}{ }^{105}$ by the inverse of the oxidation 600 rate constant of $\mathrm{Mn}\left(\mathrm{k}_{\mathrm{ox}}=0.341 \times 10^{-3} \mathrm{~h}^{-1}{ }^{106}\right)$. Interestingly, the high Mn-oxide fluxes determined at Stations \#26, \#32, \#44 and \#64 and to a lesser extent at Stations \#13 and \#38 drive other pTE fluxes. Indeed, Figure 3 shows that Mn oxides could be responsible for 3-8\% of the excess export fluxes of $\mathrm{pCu}, \mathrm{pFe}$ and $\mathrm{pNi}$.

604 Similarly, Fe-oxide fluxes are high at Stations \#32, \#38 and \#64. As seen in Figures 2 and 3, 605 Fe-oxides could represent an important carrier phase for $\mathrm{pCo}, \mathrm{pCu}, \mathrm{pMn}, \mathrm{pNi}$ and $\mathrm{pZn}$ (from 4 606 to $21 \%$ of the variance explained in the PCA on excess - i.e., non-lithogenic - fluxes, as already 607 discussed in other studies $46,107,19$. 
610 In addition to Figure 3 and Table 4, the comparison of pTE:POC ratios at each station with

611 those of phytoplankton cells suggests that biogenic particles partly influence pTE exports (Fig.

612 5). Despite large uncertainties associated with this approach, some pTE:POC ratios are

613 comparable to ratios reported for functional phytoplankton groups (diatoms, autotrophic

614 flagellates and autotrophic picoplankton) collected in the upper 150m of the North Atlantic ${ }^{71}$

615 (Fig. 5; Fig. S5). This suggests that pTE exports, and especially those of pCd, pCo, pCu, pMn,

616 and pZn, can also be driven by biogenic particles. However, higher pTE:POC ratios than cell

617 ratios are also observed. Trace elements are known to be scavenged onto particles with depth

61812,108 (see previous sections) and it is usual to observe an increase of the bulk ratios compared

619 to cellular ratios ${ }^{24,109,110}$. This can be caused by the presence of detrital, authigenic and

620 lithogenic particles on the filters leading to an increase of the pTE:POC, as observed in Figure

621 5. Moreover, the intracellular TE:C considerably changes between taxa and regions depending

622 on the environmental conditions (e.g. nutrients, sunlight limitations ${ }^{3}$ ): Fe:C quota usually

623 range between $10-1700 \mu \mathrm{g} / \mathrm{g}$ for diatoms and coccolithophorids in natural and culture

624 experiments ${ }^{3,111,112}$ but Sunda and Huntsman (1995) have measured a Fe:C ratio equalling

$6258230 \mu \mathrm{g} / \mathrm{g}^{113}$, highlighting the high variability of the ratio and the difficulty to generalize the intracellular phytoplankton TE:C ratios. Therefore, we searched for indicators of the phytoplankton community structure, such as $\mathrm{CaCO}_{3}$, opal and pigment analyses using $628 \mathrm{CHEMTAX}^{62}$. The highest $\mathrm{CaCO}_{3}$ fluxes have been determined within the west European and 629 Icelandic basins (Fig. 2) where coccolithophorids were present ${ }^{62}$. The contribution of 630 coccolithophorids to export $\mathrm{pZn}, \mathrm{pCu}, \mathrm{pNi}$ and $\mathrm{pMn}$ is indicated by relatively high correlation coefficients $(0.3<\mathrm{R}<0.5)$ between these pTEs and $\mathrm{CaCO}_{3}$ exports (Table 4). Opal fluxes are dominate the phytoplankton community ${ }^{62}$. In the Labrador Sea, high POC and opal fluxes are 
associated with surprisingly low pTE export fluxes (Fig. 2). This basin was sampled during the decline of the bloom (Station \#69: 7 weeks after the bloom peak) and was also characterized by an important remineralization event in the mesopelagic layer, evidenced from the excess barium $\left(\mathrm{Ba}_{\mathrm{xs}}\right)$ proxy ${ }^{114}$. Both results suggest either a pTE accumulation in surface waters while POC would be preferentially exported, or a limitation of dissolved TEs that would impede a pTE export due to enhanced recycling in surface waters ${ }^{115}$.

640

4.5. Residence time of TEs and efficiency of export

642 Although only few TE residence times within the upper ocean are available in the literature, the $\tau_{\text {total }}$ values estimated from the present dataset are comparable with those of other studies.

644 In the surface global ocean, the majority of $\tau_{\text {total }}$ for Fe fall between 10 and 100 days ${ }^{35}$, which corresponds to the 2-147 days range estimated in this study. Hayes et al. (2018) examined the

646 dissolved TE residence times in the upper 1000m of the North Atlantic (note the wider depth

647 layer) and found that Fe had the shortest residence time relative to other TEs, of about 30-60

648 days ${ }^{25}$. The authors estimated dissolved residence times of less than 6 years for $\mathrm{Zn}$, Co and 649 Mn (0.01 to 6 years in our study, except at Station \#64 where $\tau_{\text {total }}$ for Co reaches 14 years) and of 80-90 years for $\mathrm{Cu}(0.65-15$ years in this study; Table 5). The good consistency between

651 these different studies allows us to rank the turnover rate of TEs in the upper ocean as follows:

$652 \mathrm{Fe}<\mathrm{Zn}<\mathrm{Mn}<\mathrm{Co}<\mathrm{Cu}$.

653 In the following, our attention is mainly devoted to Fe (Fig. 6). The shortest $\tau_{\text {total }}$ (2 days) is observed close to the Iberian margin, indicating an efficient Fe export. Similar short $\tau_{\text {total }}$ within the upper ocean ( $<5$ days) have been observed in coastal areas where lithogenic particles

656 probably play an important role in transporting TEs out of the upper ocean ${ }^{32,35,88}$. These

657 lithogenic particles advected from margins may represent a continuous Fe input in surface 658 waters explaining the high inventories and export observed during GEOVIDE at Station \#1, 
even in post-bloom conditions. For example, they contribute for $98 \%$ of the total Fe export at Station \#1 (Fig. 6). As it consists of dense particles, the sinking rate of lithogenic material is

661 known to be high. Here the particle sinking rate is estimated by dividing the particulate 662 residence time by the surface-Eq depth layer. At Station 1, the sinking rate reaches $63 \mathrm{~m} / \mathrm{d}$ for $663 \mathrm{pFe}$, which is in the same order of magnitude as estimated using Stokes law $(88 \mathrm{~m} / \mathrm{d}$ for a 664 particle of $53 \mu \mathrm{m}$ diameter and of density of $1860 \mathrm{~kg} / \mathrm{m}^{3}$, representing an average density for a mixed aggregate composed of lithogenic, transparent exopolymer particles (TEP), detritus, opal and $\left.\mathrm{CaCO}_{3} ;{ }^{116}\right)$. Similarly, high particulate and dissolved inventories, high export fluxes and short $\tau_{\text {total }}$ are observed at Station \#1 for other TEs, suggesting a fast supply to and removal 668 from the upper ocean by lithogenic particles (Table 5). However, $\tau_{\text {total }}$ values for $\mathrm{Mn}$, $\mathrm{Zn}$ and $669 \mathrm{Ni}$ at Station \#1 are not the shortest observed along the transect, indicating that lithogenic 670 particles are not the only drivers of TE export, even at this coastal station.

671 The Icelandic and western European basins were sampled during the bloom development and 672 were thus characterized by an important productivity event ${ }^{60,61}$. In these basins, we observe a $673 \tau_{\text {total }}$ averaging 3 days for Fe, suggesting an efficient transport to the deep ocean. As seen 674 previously, Stations \#21, \#32 and \#38 are characterized by high export fluxes of Fe- and Mn675 oxides, carrying other TEs to the deep ocean. At these stations, $\mathrm{pFe}$ sinks faster compared to the Iberian margin (up to $135 \mathrm{~m} / \mathrm{d}$ at Station \#32), likely because of the presence of Fe-oxides

677 (contributing to $62 \%$ of total Fe export in these basins; Fig. 6). These mineral phases are 678 presumably denser than lithogenic particles (the density of ferrihydrite is about $3.8 \mathrm{~g} / \mathrm{cm}^{3}$ 679 compared to a typical clay density of $2.7 \mathrm{~g} / \mathrm{cm}^{3}$ ) but the sinking speed is also controlled by the 680 size of the particle, which might be an important factor in the west European and Icelandic basins. Other TEs also have short $\tau_{\text {total }}$ and high sinking rates in these basins, confirming the important contribution of oxides to export pTEs. 
683 Finally, the Labrador and Irminger basins were sampled during the bloom decline and the

684

685

686

687

688

689

690

691

692

693

694

695

696

697

698

699

700

701

702

703

704

705

706

707 average pFe export flux is the lowest of the whole transect $\left(182 \mu \mathrm{g} / \mathrm{m}^{2} / \mathrm{d}\right.$ compared to 441 and $3912 \mu \mathrm{g} / \mathrm{m}^{2} / \mathrm{d}$ for respectively the west European/Icelandic basins and Iberian margin). Longer residence times are also determined within the Labrador and Irminger basins, suggesting that most of $\mathrm{pFe}$ is not exported as efficiently as in the eastern basins. This may be due to the more important fraction of Fe carried by biogenic matter (12\% compared to 1 and $3 \%$ in the Iberian and west European/Icelandic basins, respectively), leading to a slower export of Fe and/or active recycling processes. The median sinking rate of $3 \mathrm{~m} / \mathrm{d}$ (Table 5) is similar to the rate estimated by using Stokes law $(3.5 \mathrm{~m} / \mathrm{d})$ for an organic particle of $53 \mu \mathrm{m}$ diameter and a density of $1060 \mathrm{~kg} / \mathrm{m}^{3}$. Indeed, Fe removal rate from the upper ocean via biological processes has been shown to be much smaller than via lithogenic and authigenic processes ${ }^{35}$. A greater $\tau_{\text {total }}$ is also estimated for other TEs. The slower removal of biogenic TEs can also be reflected by the longer residence times of less detrital TEs, such as $\mathrm{Ni}$, $\mathrm{Co}$ or $\mathrm{Cu}$ (from 65 days to > 35 years) compared to more detrital TEs (Al, Fe with $\tau_{\text {total }}<150$ days).

\section{CONCLUSION}

Using the ${ }^{234} \mathrm{Th}$ approach and the elemental composition of large, sinking particles, this study investigated the pTE export fluxes, sinking rates and residence times in the North Atlantic.

Lithogenic material is present everywhere along the section, but mainly controls the fluxes near the Iberian margin, where the highest pTE fluxes are observed. As a result, TE residence time in the upper ocean is short in vicinity of the Iberian Margin. In the open ocean, and especially within the Icelandic basin, Mn- and Fe-oxides are likely the main TE carriers to the deep ocean. Zinc and $\mathrm{Ni}$, for example, have shorter residence times there compared to the Iberian basin which is under lithogenic influence. Biogenic particles also contribute to export pTEs, as reflected by the similarity of pTE:POC export ratios and TE:C cell ratios. Particulate TE export 
708 fluxes especially those of $\mathrm{pZn}, \mathrm{pCu}, \mathrm{pNi}$ and $\mathrm{pMn}$ might be enhanced by sinking 709 coccolithophorid cells within the west European and Icelandic basins, where $\mathrm{CaCO}_{3}$ exports

710 are the highest. Diatoms are dominating the phytoplankton community within the Irminger and 711 Labrador basins, in agreement with the highest opal fluxes. However there, pTE fluxes are low, 712 possibly suggesting TE recycling due to dissolved TE limitations in surface waters, in line with 713 the decline of the bloom. The inefficient pTE export in this area is also illustrated by the longer 714 residence times, which may be due to greater biogenic contribution. 
a)

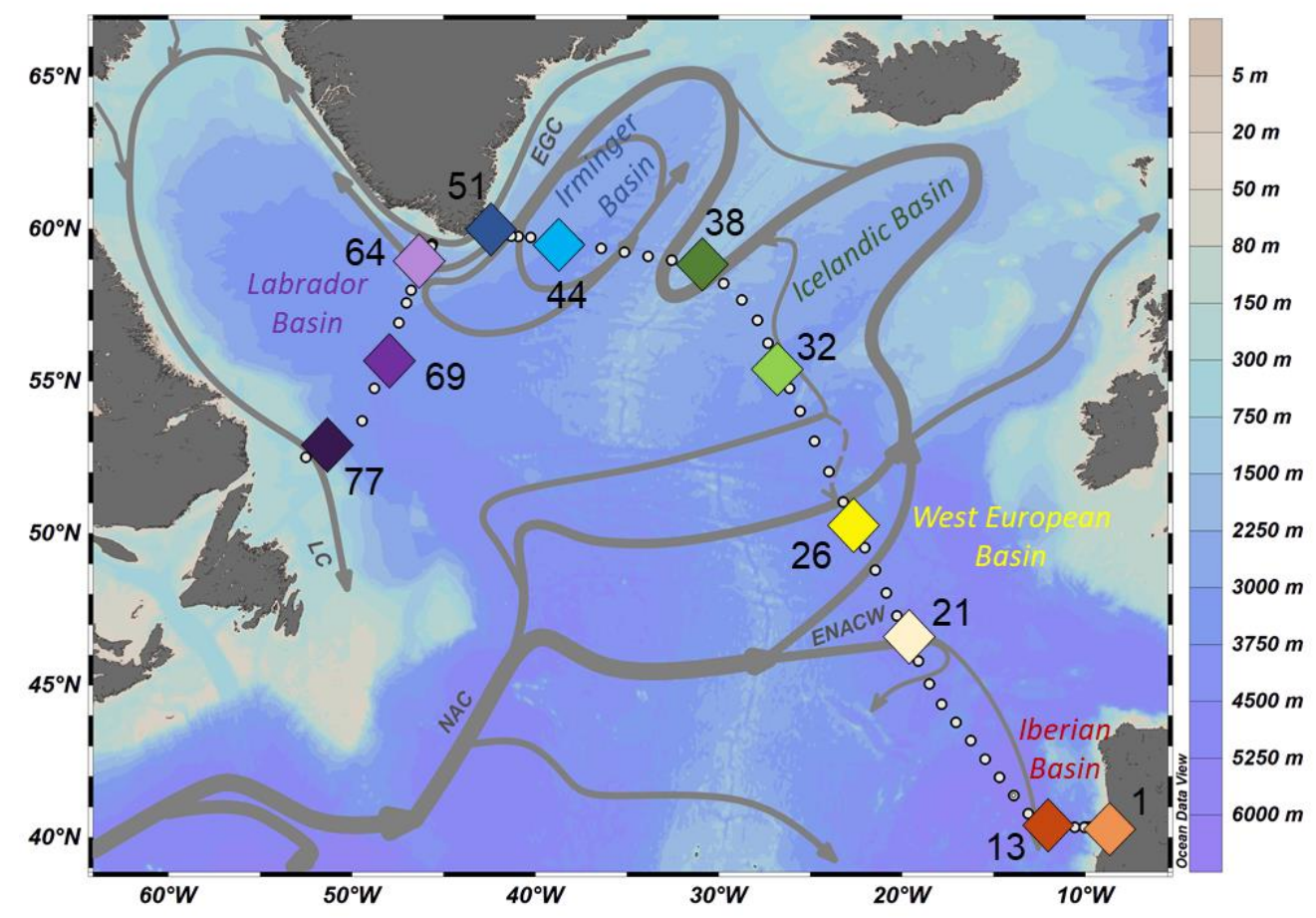

b)
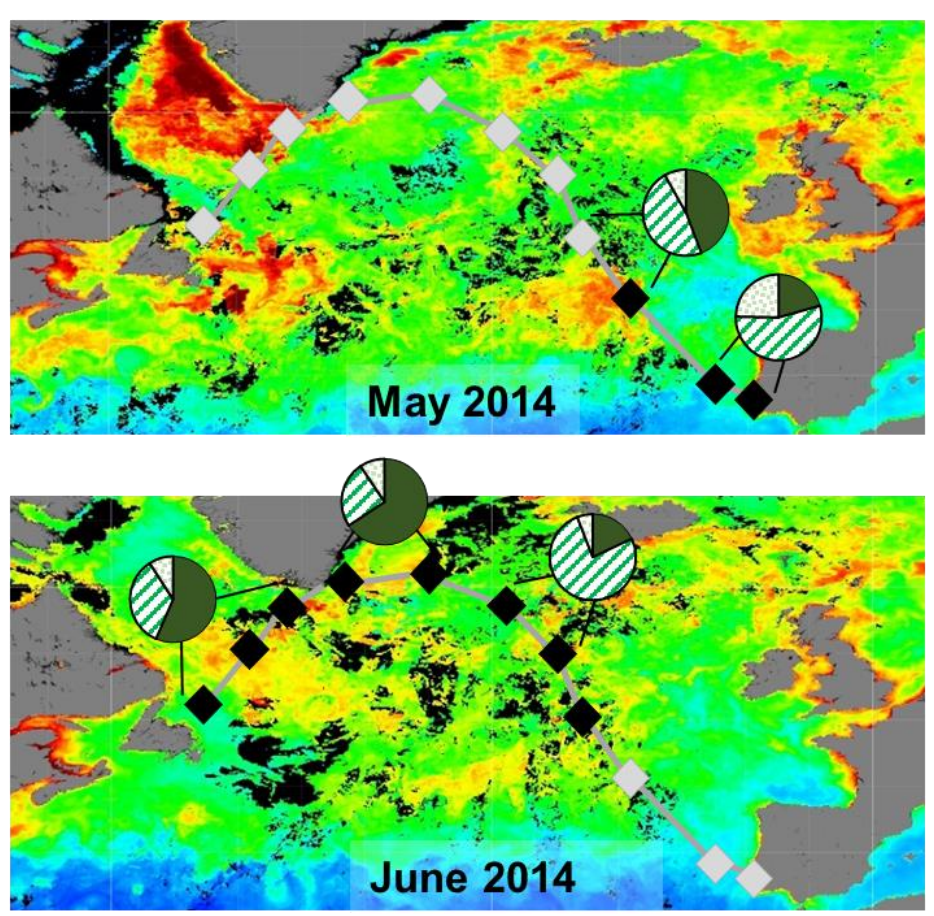

Chlorophyll a concentrations $\left(\mathrm{mg} / \mathrm{m}^{3}\right)$ $\begin{array}{lllllll}0.01 & 0.03 & 0.1 & 0.3 & 1 & 3 & 10\end{array}$

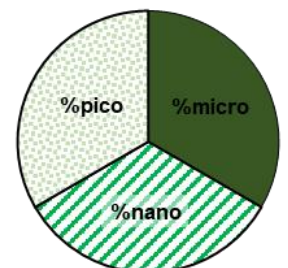


717 Figure 1: a) Schematic diagram of the surface circulation superimposed on the bathymetric map of the North Atlantic ${ }^{117}$. Coloured symbols 718 represent the stations discussed in this study (red: Iberian basin; yellow: West European basin; green: Icelandic basin; blue: Irminger basin; purple:

719 Labrador basin). Abbreviations for the main surface hydrographic features in the upper 500m indicate the East North Atlantic Central Water 720 (ENACW), Labrador Current (LC), East Greenland Current (EGC) and the North Atlantic Current (NAC). b) Satellite-derived chlorophyll- $a$ 721 concentrations (MODIS Aqua from oceancolor.gsfc.nasa.gov) averaged over May (top panel) and June (bottom panel) 2014. The GEOVIDE 722 transect is indicated by the grey line and black symbols indicate stations sampled during the corresponding month. The pie charts indicate the 723 proportion of micro-phytoplankton (dark green), nano-phytoplankton (hatched green) and pico-phytoplankton (dotted light green) encountered in 724 each basin during GEOVIDE ${ }^{62}$. 
FIGURE 2
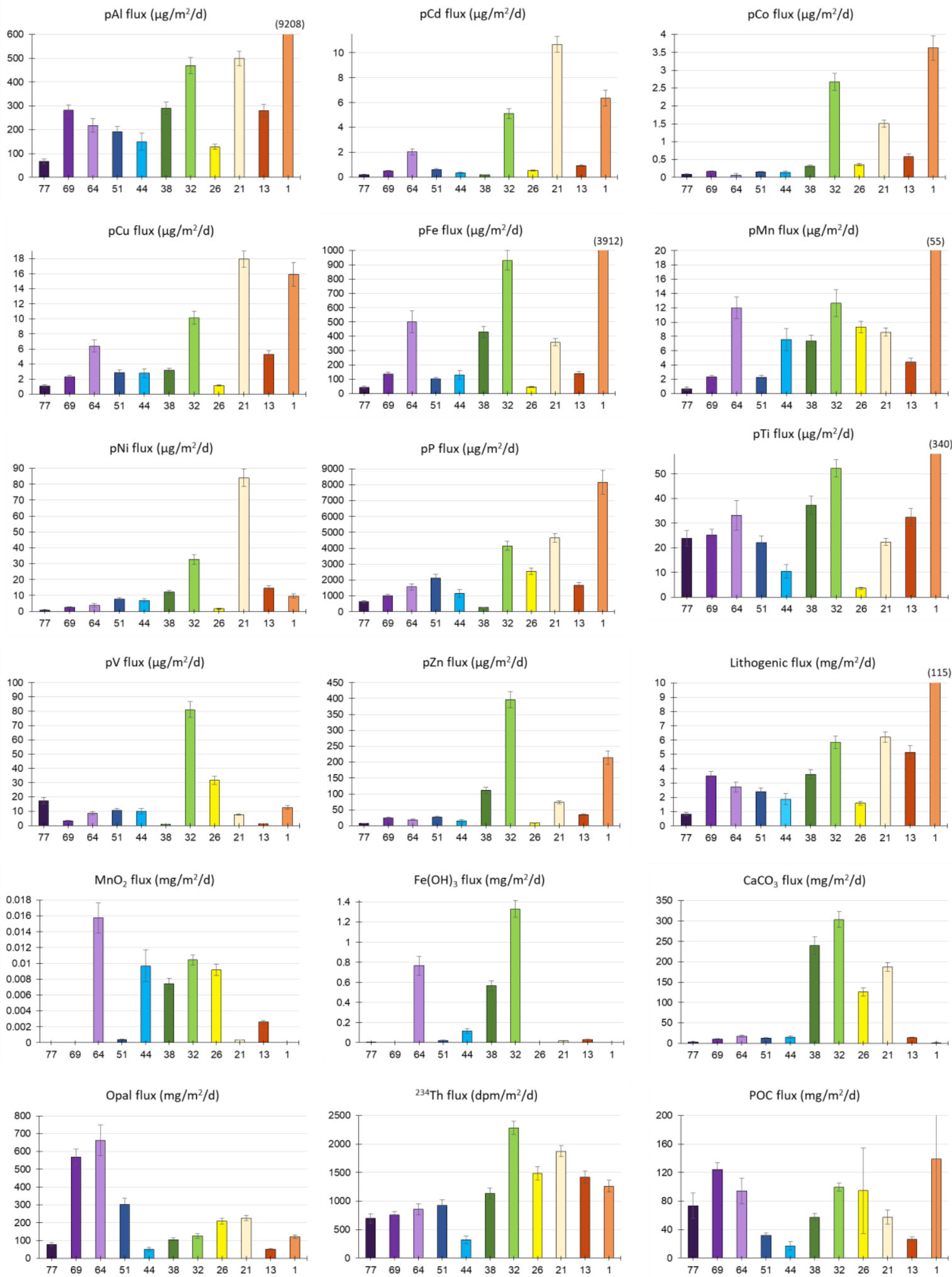

Figure 2: Particulate trace element and mineral export fluxes in $\mu \mathrm{g} / \mathrm{m}^{2} / \mathrm{d}$ or $\mathrm{mg} / \mathrm{m}^{2} / \mathrm{d}$ estimated 729 in the large size fraction at the Eq depth. ${ }^{234} \mathrm{Th}$ (in $\mathrm{dpm} / \mathrm{m}^{2} / \mathrm{d}$ ) and POC (in $\mathrm{mg} / \mathrm{m}^{2} / \mathrm{d}$ ) export 730 fluxes in the large size fraction and at the Eq depth are also presented for comparison ${ }^{60}$. 
FIGURE 3

732

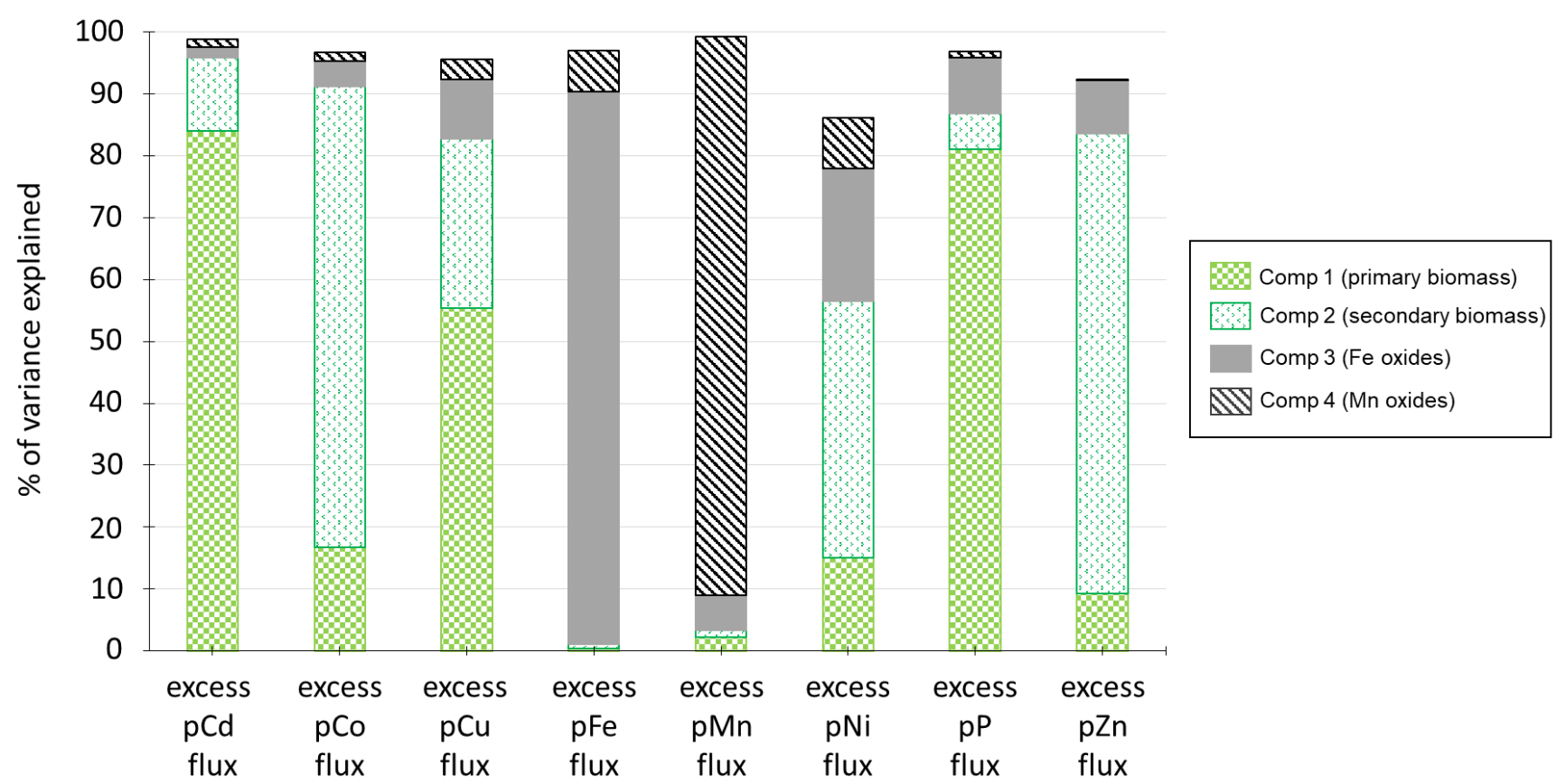

733 Figure 3: Variance explained for eight excess pTE export fluxes at Eq, captured by the first

734 four principal components in principal component analysis (XLStat software). The description

735 of the components is provided in the text. Excess pTE export fluxes are calculated by removing the

736 lithogenic fraction of the flux (excess pTE flux = pTE flux $-\left[\mathrm{pAl}\right.$ flux $\times\left(\frac{\boldsymbol{p T E}}{\boldsymbol{p A l}}\right)$ Ucc $]$; with the UCC ratio 737 from ${ }^{67}$ ). 


\section{FIGURE 4}
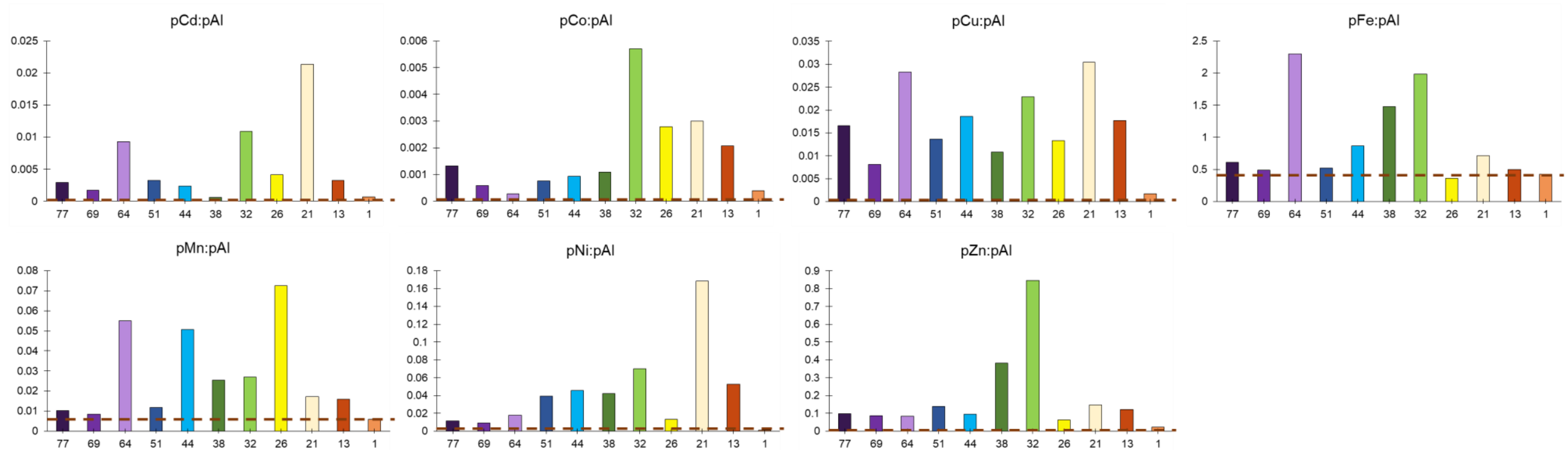

Figure 4: Ratios of the pTEs over pAl fluxes (in $\mathrm{g} / \mathrm{g}$, on $\mathrm{y}$-axis) determined at Eq along the GEOVIDE transect (station numbers on $\mathrm{x}$-axis). The brown horizontal dashed lines represent the ratios for the upper continental crust (UCC) ${ }^{67}$. 


\section{FIGURE 5}
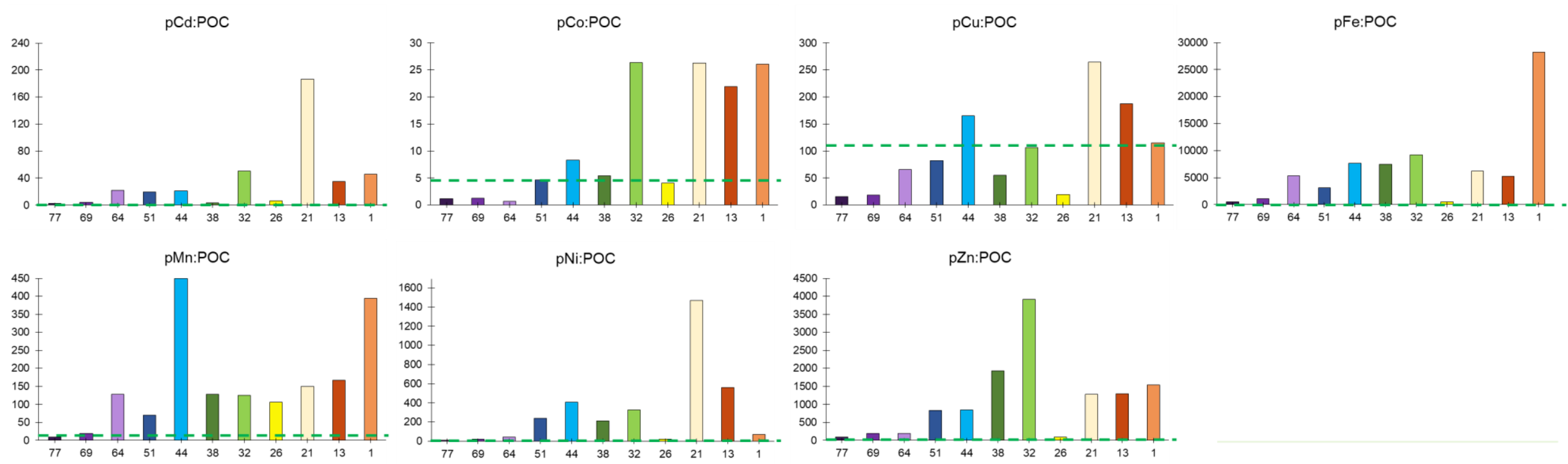

Figure 5: Ratios of the pTEs over particulate organic carbon (POC) fluxes (in $\mu \mathrm{g} / \mathrm{g}$, on $\mathrm{y}$-axis) determined at Eq along the GEOVIDE transect

(station numbers on $\mathrm{x}$-axis). The green horizontal dashed lines indicate the average intracellular metal stoichiometries ${ }^{71}$. 


\section{FIGURE 6}

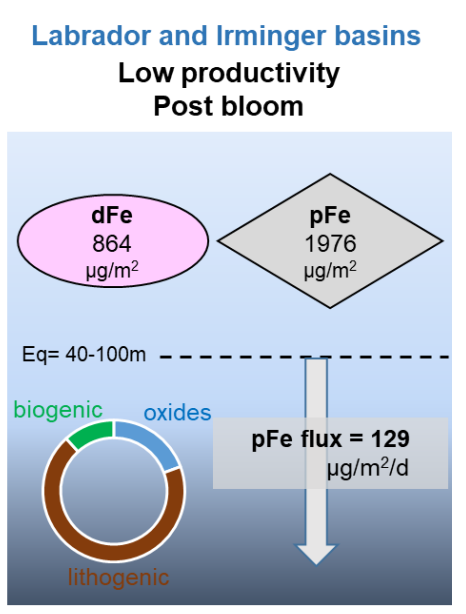

Residence time in Eq: 16 days

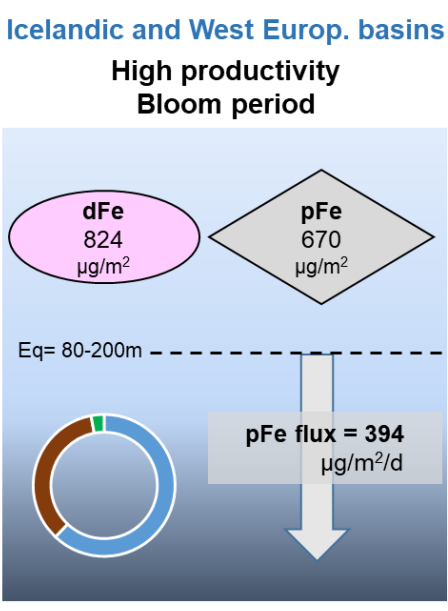

Residence time in Eq: 4 days

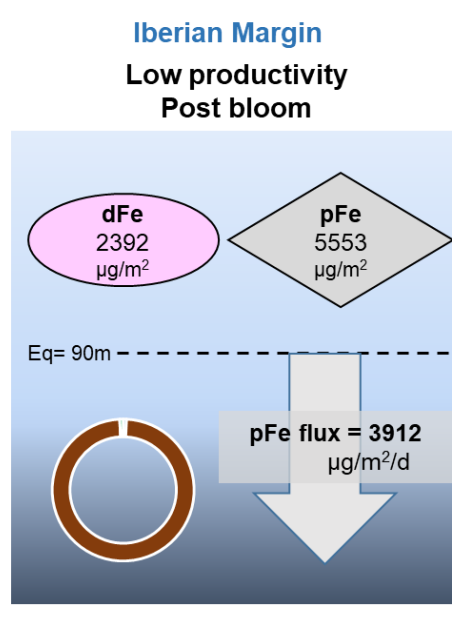

Residence time in Eq: 2 days

Figure 6: Biogeochemical iron budget in the upper ocean for the Labrador and Irminger basins (left box), for the Icelandic and west European basins (middle box) and for the Iberian margin (right box). For each area, we show the median inventories of dissolved iron $\left(\mathrm{dFe}{ }^{85}\right.$; pink circles) and particulate iron ( $\mathrm{pFe}^{65}$; grey diamonds) in $\mu \mathrm{g} / \mathrm{m}^{2}$, the median particulate iron fluxes (pFe flux; grey rectangles) in $\mu \mathrm{g} / \mathrm{m}^{2} / \mathrm{d}$ and the median total residence times $\left(\tau_{\text {tot }}\right)$ in days. The total residence time is calculated for the depth interval 0-Eq. The size of the arrows is roughly proportional to the magnitude of the $\mathrm{pFe}$ fluxes. The fractions of the $\mathrm{pFe}$ flux driven by lithogenic, authigenic or biogenic particles are represented by the brown, blue and green colours, respectively. Lithogenic pFe flux was estimated by multiplying the pAl flux by the pFe:pAl ratio in the upper continental crust (UCC, i.e., $0.44 \mathrm{~g} / \mathrm{g}$ ) ${ }^{67}$. Authigenic $\mathrm{pFe}$ flux is equal to the $\mathrm{Fe}(\mathrm{OH})_{3}$ flux (see details in section 2.3) and the biogenic pFe flux is obtained by multiplying the POC flux ${ }^{60}$ by an average $\mathrm{Fe}: \mathrm{C}$ ratio determined in phytoplankton cells of the North Atlantic $(193.7 \mu \mathrm{g} / \mathrm{g})^{71}$. 


\section{TABLE 1}

\begin{tabular}{cccccc}
\hline Station & $\begin{array}{c}\text { Number of weeks } \\
\text { since beginning of } \\
\text { spring bloom }\end{array}$ & $\begin{array}{c}\text { In-situ primary } \\
\text { production } \\
\left(\mathrm{mmol} / \mathrm{m}^{2} / \mathrm{d}\right)\end{array}$ & Phytoplankton class & $\begin{array}{c}\text { POC export } \\
\left(\mathrm{mmol} / \mathrm{m}^{2} / \mathrm{d}\right)\end{array}$ \\
\hline Iberian & 1 & 10 & 33 & diatoms \& coccolith. & 12 \\
basin & 13 & 11 & 79 & pelagophytes \& cyano. & 2.2 \\
\hline west Europ. & 21 & 9 & 135 & diatoms & 4.8 \\
Basin & 26 & 8 & 174 & diatoms & 7.9 \\
\hline Icelandic & 32 & 5 & 105 & coccolith. & 8.3 \\
basin & 38 & 4 & 68 & coccolith. & 4.8 \\
\hline Irminger & 44 & 5 & 137 & diatoms & 1.4 \\
basin & 51 & 4 & 166 & diatoms & 2.7 \\
\hline Labrador & 64 & 5 & 54 & diatoms & 7.8 \\
basin & 69 & 4 & 27 & diatoms & 10 \\
\hline
\end{tabular}

Table 1: Station characteristics with the number of weeks between the sampling time and beginning of the spring bloom (obtained from satellite data products ${ }^{60}$ ), primary production (obtained from incubations ${ }^{61}$ ), POC export fluxes (obtained with the ${ }^{234}$ Th approach ${ }^{60}$ ), and phytoplankton classes (from HPLC pigment analysis and CHEMTAX analysis ${ }^{62}$ ). 
TABLE 2

\begin{tabular}{lccccccccccccc}
\hline & $\mathbf{A l}^{+}$ & $\mathrm{Ca}^{+}$ & $\mathbf{C d}$ & $\mathrm{Co}^{*}$ & $\mathbf{C u}$ & $\mathrm{Fe}^{*}$ & $\mathbf{M n}$ & $\mathbf{N a}^{\mathbf{N}}$ & $\mathbf{N i}$ & $\mathbf{P}^{+}$ & $\mathrm{Ti}^{+}$ & $\mathbf{V}$ & $\mathrm{Zn}^{+}$ \\
\hline Blank (ppm) & $1.6 \mathrm{E}-03$ & 1.4 & $1.2 \mathrm{E}-06$ & $3.2 \mathrm{E}-06$ & $1.3 \mathrm{E}-05$ & $1.5 \mathrm{E}-03$ & $1.4 \mathrm{E}-04$ & 936 & $3.4 \mathrm{E}-04$ & $2.5 \mathrm{E}-03$ & $1.0 \mathrm{E}-04$ & $7.3 \mathrm{E}-06$ & $2.6 \mathrm{E}-04$ \\
BCR-414 (n=5; ppm) & 3112 & 51133 & 0.385 & 1.44 & 29.7 & 1860 & 301 & 6601 & 17.8 & 15541 & 95 & 9 & 112.4 \\
RSD (\%) & 15 & 2.1 & 5.2 & 15 & 13 & 12 & 14 & 0.2 & 16 & 24 & 8 & 1 & 17 \\
Recovery CRM (\%) & 118 & 80 & 101 & 101 & 101 & 101 & 101 & $/$ & 95 & 113 & 75 & 111 & 101
\end{tabular}

Table 2: Blanks, average concentrations of the certified reference material (CRM; BCR-414), relative standard deviation (RSD) of the 5

analyses of the CRM and recoveries. Elements without any superscript sign have certified concentrations $(\mathrm{Cd}, \mathrm{Cu}, \mathrm{Mn}, \mathrm{Ni}, \mathrm{V}$ and $\mathrm{Zn})$; elements marked with $\left(^{*}\right)$ have indicative concentrations reported on the official certificate (Co and Fe); elements marked with $\left(^{+}\right)$have indicative concentrations reported on the GEOREM website (Al, Ca, P, and Ti) and Na has no reported concentration. The official certificate can be found at https://crm.jrc.ec.europa.eu/p/40455/40461/By-material-matrix/Animal-materials/BCR-414-PLANKTON-trace-elements/BCR-414 . 


\section{TABLE 3}

\begin{tabular}{|c|c|c|c|c|c|c|c|c|c|c|c|c|c|c|c|c|c|c|c|c|c|c|c|c|}
\hline \multirow[t]{2}{*}{ Basin } & \multirow[t]{2}{*}{ Station } & \multirow{2}{*}{$\begin{array}{c}\mathrm{Eq} \\
\mathrm{m}\end{array}$} & \multicolumn{2}{|c|}{ Al flux } & \multicolumn{2}{|c|}{ Cd flux } & \multicolumn{2}{|c|}{ Co flux } & \multicolumn{2}{|c|}{ Cu flux } & \multicolumn{2}{|c|}{ Fe flux } & \multicolumn{2}{|c|}{ Mn flux } & \multicolumn{2}{|c|}{ Ni flux } & \multicolumn{2}{|c|}{ P flux } & \multicolumn{2}{|c|}{ Ti flux } & \multicolumn{2}{|c|}{$V$ flux } & \multicolumn{2}{|c|}{ Zn flux } \\
\hline & & & $\mathrm{\mu g} / \mathrm{m}^{2} / \mathrm{d}$ & $\mathrm{sd}$ & $\mathrm{\mu g} / \mathrm{m}^{2} / \mathrm{d}$ & sd & $\mu \mathrm{g} / \mathrm{m}^{2} / \mathrm{d}$ & sd & $\mu \mathrm{g} / \mathrm{m}^{2} / \mathrm{d}$ & $\mathrm{sd}$ & $\mu \mathrm{g} / \mathrm{m}^{2} / \mathrm{d}$ & sd & $\mu \mathrm{g} / \mathrm{m}^{2} / \mathrm{d}$ & $\mathrm{sd}$ & $\mu \mathrm{g} / \mathrm{m}^{2} / \mathrm{d}$ & sd & $\mu \mathrm{g} / \mathrm{m}^{2} / \mathrm{d}$ & sd & $\mu \mathrm{g} / \mathrm{m}^{2} / \mathrm{d}$ & $\mathrm{sd}$ & $\mu \mathrm{g} / \mathrm{m}^{2} / \mathrm{d}$ & $\mathrm{sd}$ & $\mu \mathrm{g} / \mathrm{m}^{2} / \mathrm{d}$ & sd \\
\hline \multirow{2}{*}{ Iberian } & 1 & 90 & 9208 & 883 & 6.4 & 0.6 & 3.6 & 0.3 & 16 & 2 & 3912 & 364 & 55 & 6 & 9.7 & 1.4 & 8141 & 758 & 340 & 34 & 13 & 1 & 214 & 21 \\
\hline & 13 & 110 & 280 & 26 & 0.9 & 0.1 & 0.58 & 0.08 & 5.0 & 0.5 & 138 & 15 & 4.4 & 0.5 & 15 & 1 & 1673 & 160 & 32 & 4 & 1.2 & 0.1 & 34 & 3 \\
\hline west & 21 & 110 & 500 & 30 & 10.7 & 0.6 & 1.5 & 0.1 & 15 & 1 & 358 & 25 & 8.6 & 0.6 & 84 & 6 & 4648 & 278 & 22 & 1 & 7.8 & 0.5 & 74 & 5 \\
\hline Europ. & 26 & 100 & 128 & 11 & 0.53 & 0.05 & 0.36 & 0.03 & 1.7 & 0.1 & 46 & 4 & 9.3 & 0.8 & 1.7 & 0.2 & 2537 & 212 & 3.5 & 0.4 & 32 & 3 & 8 & 1 \\
\hline \multirow{2}{*}{ Icelandic } & 32 & 130 & 469 & 35 & 5.1 & 0.4 & 2.7 & 0.2 & 11 & 1 & 931 & 69 & 13 & 2 & 33 & 3 & 4145 & 285 & 52 & 4 & 81 & 5 & 396 & 25 \\
\hline & 38 & 80 & 290 & 26 & 0.18 & 0.02 & 0.31 & 0.03 & 3.1 & 0.3 & 429 & 40 & 7.4 & 0.8 & 12 & 1 & 266 & 24 & 37 & 4 & 1.0 & 0.1 & 111 & 10 \\
\hline \multirow{2}{*}{ Irminger } & 44 & 40 & 150 & 36 & 0.36 & 0.07 & 0.14 & 0.04 & 2.8 & 0.6 & 129 & 30 & 7.6 & 1.6 & 6.9 & 1.1 & 1158 & 237 & 10 & 3 & 10 & 2 & 14 & 6 \\
\hline & 51 & 100 & 192 & 22 & 0.63 & 0.07 & 0.15 & 0.02 & 2.6 & 0.3 & 101 & 12 & 2.2 & 0.3 & 7.6 & 1.0 & 2105 & 242 & 22 & 3 & 11 & 1 & 26 & 3 \\
\hline \multirow{3}{*}{ Labrador } & 64 & 80 & 218 & 29 & 2.0 & 0.2 & 0.06 & 0.05 & 6.2 & 0.8 & 501 & 77 & 12 & 2 & 3.8 & 1.2 & 1562 & 185 & 33 & 6 & 8.6 & 1.0 & 18 & 2 \\
\hline & 69 & 40 & 281 & 23 & 0.49 & 0.04 & 0.16 & 0.01 & 2.3 & 0.2 & 137 & 11 & 2.4 & 0.2 & 2.6 & 0.3 & 1017 & 82 & 25 & 2 & 3.2 & 0.3 & 24 & 2 \\
\hline & 77 & 60 & 67 & 10 & 0.19 & 0.02 & 0.09 & 0.01 & 1.1 & 0.1 & 41 & 10 & 0.7 & 0.2 & 0.8 & 0.3 & 627 & 73 & 24 & 3 & 17 & 2 & 7 & 1 \\
\hline
\end{tabular}

\begin{tabular}{ccc|cc|cc|cc|cc|cc|cc}
\hline Basin & Station & Eq & \multicolumn{2}{|c|}{ Lithogenic flux } & \multicolumn{2}{|c|}{$\mathrm{Fe}(\mathrm{OH})_{3}$ flux } & \multicolumn{2}{|c|}{$\mathrm{MnO}_{2}$ flux } & \multicolumn{2}{|c|}{$\mathrm{CaCO}_{3}$ flux } & \multicolumn{2}{|c|}{ Opal flux } & \multicolumn{2}{|c}{${ }^{234} \mathrm{Th}$ flux } \\
& & $\mathrm{m}$ & $\mathrm{mg} / \mathrm{m}^{2} / \mathrm{d}$ & $\mathrm{sd}$ & $\mathrm{mg} / \mathrm{m}^{2} / \mathrm{d}$ & $\mathrm{sd}$ & $\mathrm{mg} / \mathrm{m}^{2} / \mathrm{d}$ & $\mathrm{sd}$ & $\mathrm{mg} / \mathrm{m}^{2} / \mathrm{d}$ & $\mathrm{sd}$ & $\mathrm{mg} / \mathrm{m}^{2} / \mathrm{d}$ & $\mathrm{sd}$ & $\mathrm{dpm} / \mathrm{m}^{2} / \mathrm{d}$ & $\mathrm{sd}$ \\
\hline \multirow{2}{*}{ Iberian } & 1 & 90 & 115 & 11 & $\mathrm{nd}$ & $\mathrm{nd}$ & $\mathrm{nd}$ & $\mathrm{nd}$ & $\mathrm{nd}$ & $\mathrm{nd}$ & 122 & 10 & 1264 & 104 \\
& 13 & 110 & 3.5 & 0.3 & 0.032 & 0.003 & 0.0026 & 0.0002 & 14 & 1 & 52 & 4 & 1418 & 111 \\
\hline \multirow{2}{*}{ west } & 21 & 110 & 6.2 & 0.4 & 0.020 & 0.001 & 0.00032 & 0.00002 & 187 & 10 & 226 & 14 & 1873 & 97 \\
Europ. & 26 & 100 & 1.6 & 0.1 & $\mathrm{nd}$ & $\mathrm{nd}$ & 0.009 & 0.001 & 126 & 10 & 209 & 17 & 1486 & 117 \\
\hline \multirow{2}{*}{ Icelandic } & 32 & 130 & 5.8 & 0.4 & 1.3 & 0.1 & 0.010 & 0.001 & 303 & 19 & 127 & 13 & 2282 & 119 \\
& 38 & 80 & 3.6 & 0.3 & 0.57 & 0.05 & 0.007 & 0.001 & 240 & 21 & 105 & 9 & 1134 & 95 \\
\hline \multirow{2}{*}{ Irminger } & 44 & 40 & 1.9 & 0.4 & 0.11 & 0.02 & 0.010 & 0.002 & 15 & 3 & 51 & 11 & 321 & 66 \\
& 51 & 100 & 2.4 & 0.3 & 0.024 & 0.003 & 0.00038 & 0.00004 & 12 & 1 & 303 & 34 & 922 & 103 \\
\hline \multirow{3}{*}{ Labrador } & 64 & 80 & 2.7 & 0.4 & 0.8 & 0.1 & 0.016 & 0.002 & 17 & 2 & 661 & 86 & 855 & 95 \\
& 69 & 40 & 3.5 & 0.3 & nd & nd & nd & nd & 10 & 1 & 568 & 46 & 758 & 57 \\
& 77 & 60 & 0.8 & 0.1 & 0.0 & 0.0 & nd & nd & 3 & 1 & 79 & 9 & 696 & 77 \\
\hline
\end{tabular}

Table 3: Particulate export fluxes in $\mu \mathrm{g} / \mathrm{m}^{2} / \mathrm{d}$ for aluminum (pAl), cadmium (pCd), cobalt (pCo), copper (pCu), iron (pFe), manganese (pMn), nickel (pNi), phosphorus (pP), titanium (pTi), vanadium (pV) and zinc (pZn); in mg/m²/d for lithogenic material, iron oxides $\left(\mathrm{Fe}(\mathrm{OH})_{3}\right)$, manganese oxides $\left(\mathrm{MnO}_{2}\right)$, calcium carbonate $\left(\mathrm{CaCO}_{3}\right)$, opal and in $\mathrm{dpm} / \mathrm{m}^{2} / \mathrm{d}$ for ${ }^{234} \mathrm{Th}$. Standard deviations (sd) were calculated by considering the standard deviations of the ${ }^{234} \mathrm{Th}$ fluxes and pTE: ${ }^{234} \mathrm{Th}$ ratios at Eq, with all concentration and activity uncertainties estimated using error propagation law. 
TABLE 4

\begin{tabular}{|c|c|c|c|c|c|c|c|c|c|c|c|c|c|c|c|c|c|}
\hline Lithogenic flux & 1 & & & & & & & & & & & & & & & & \\
\hline $\mathrm{MnO}_{2}$ flux & & 0.769 & 1 & & & & & & & & & & & & & & \\
\hline $\mathrm{CaCO}_{3}$ flux & 0.200 & 0.633 & 0.706 & 1 & & & & & & & & & & & & & \\
\hline Opal flux & 0.164 & & 0.028 & 0.073 & 1 & & & & & & & & & & & & \\
\hline Cd flux & 0.618 & 0.018 & 0.037 & 0.100 & 0.364 & 0.273 & 0.618 & 1 & & & & & & & & & \\
\hline Co flux & 0.745 & & & 0.200 & & 0.282 & 0.745 & 0.591 & 1 & & & & & & & & \\
\hline Cu flux & 0.845 & 0.330 & 0.156 & 0.255 & 0.064 & 0.191 & 0.845 & 0.791 & 0.609 & 1 & & & & & & & \\
\hline Fe flux & 0.855 & 0.395 & 0.220 & 0.273 & 0.145 & 0.455 & 0.855 & 0.591 & 0.527 & 0.900 & 1 & & & & & & \\
\hline Mn flux & 0.527 & 0.183 & 0.440 & 0.364 & 0.136 & 0.473 & 0.527 & 0.636 & 0.527 & 0.718 & 0.736 & 1 & & & & & \\
\hline Zn flux & 0.909 & 0.303 & 0.000 & 0.318 & 0.018 & 0.245 & 0.909 & 0.527 & 0.764 & 0.791 & 0.818 & 0.464 & 0.855 & 0.464 & 0.718 & & 1 \\
\hline
\end{tabular}

Table 4: Spearman rank correlation coefficients between trace element and mineral export fluxes for the large size fraction at the Eq depth. The analysis was conducted on log-transformed export fluxes to ensure that input variables were more normally distributed and to reduce the influence of extreme values. Correlations with $\mathrm{R}<0.1$ are not shown. Values in bold are correlation coefficients with p-value $\leq 0.05$ (t-test; XLStat software). 


\section{TABLE 5}

\begin{tabular}{|c|c|c|c|c|c|c|c|c|c|c|c|c|c|c|c|c|c|c|c|c|c|}
\hline \multirow{3}{*}{ Basin } & \multirow{3}{*}{ Station } & \multicolumn{5}{|c|}{ Al } & \multicolumn{5}{|c|}{ Co } & \multicolumn{5}{|c|}{$\mathrm{Cu}$} & \multicolumn{5}{|c|}{$\mathrm{Fe}$} \\
\hline & & \multirow{2}{*}{$\begin{array}{c}\text { diss. invent. } \\
\mu \mathrm{g} / \mathrm{m}^{2}\end{array}$} & \multirow{2}{*}{$\begin{array}{c}\text { part. invent. } \\
\mu \mathrm{g} / \mathrm{m}^{2}\end{array}$} & \multirow{2}{*}{$\begin{array}{c}\text { sinking rate } \\
\mathrm{m} / \mathrm{d}\end{array}$} & \multicolumn{2}{|c|}{$\tau_{\text {tot }}$} & \multirow{2}{*}{$\begin{array}{c}\text { diss. invent. } \\
\mu \mathrm{g} / \mathrm{m}^{2}\end{array}$} & \multirow{2}{*}{$\begin{array}{c}\text { part. invent. } \\
\mu \mathrm{g} / \mathrm{m}^{2}\end{array}$} & \multirow{2}{*}{$\begin{array}{c}\text { sinking rate } \\
\mathrm{m} / \mathrm{d}\end{array}$} & \multicolumn{2}{|c|}{$\tau_{\text {tot }}$} & \multirow{2}{*}{$\begin{array}{c}\text { diss. invent. } \\
\mu \mathrm{g} / \mathrm{m}^{2}\end{array}$} & \multirow{2}{*}{$\begin{array}{c}\text { part. invent. } \\
\mu \mathrm{g} / \mathrm{m}^{2}\end{array}$} & \multirow{2}{*}{$\begin{array}{c}\text { sinking rate } \\
\mathrm{m} / \mathrm{d}\end{array}$} & \multicolumn{2}{|c|}{$\tau_{\text {tot }}$} & \multirow{2}{*}{$\begin{array}{c}\text { diss. invent. } \\
\mu \mathrm{g} / \mathrm{m}^{2}\end{array}$} & \multirow{2}{*}{$\begin{array}{c}\text { part. invent. } \\
\mu \mathrm{g} / \mathrm{m}^{2}\end{array}$} & \multirow{2}{*}{$\begin{array}{c}\text { sinking rate } \\
\mathrm{m} / \mathrm{d}\end{array}$} & \multicolumn{2}{|c|}{$\tau_{\text {tot }}$} \\
\hline & & & & & d & $\mathrm{sd}$ & & & & $\mathrm{d}$ & $\mathrm{sd}$ & & & & d & $\mathrm{sd}$ & & & & $\mathrm{d}$ & $\mathrm{sd}$ \\
\hline \multirow{2}{*}{ Iberian } & 1 & 20847 & 12741 & 65 & 4 & 0.2 & 219 & 13 & 25 & 64 & 3 & 3718 & 28 & 52 & 236 & 11 & 2392 & 5553 & 63 & 2 & 0.1 \\
\hline & 13 & 7720 & 6672 & 5 & 51 & 5 & 124 & 32 & 2 & 269 & 29 & 5002 & 129 & 4 & 1033 & 110 & 1564 & 1139 & 13 & 20 & 2 \\
\hline west & 21 & 13038 & 3628 & 15 & 33 & 1 & 151 & 37 & 5 & 125 & 5 & 6224 & 186 & 9 & 422 & 19 & 861 & 599 & 66 & 4 & 0.2 \\
\hline Europ. & 26 & 6181 & 1741 & 7 & 62 & 12 & 195 & 20 & 2 & 598 & 114 & 6100 & 133 & 1 & 3646 & 698 & 691 & 741 & 6 & 31 & 6 \\
\hline \multirow{2}{*}{ Icelandic } & 32 & 12630 & 1465 & 42 & 30 & 4 & 224 & 22 & 16 & 92 & 11 & 5539 & 202 & 7 & 534 & 66 & 1471 & 898 & 135 & 3 & 0.3 \\
\hline & 38 & 6007 & 716 & 32 & 23 & 1 & 111 & 9 & 3 & 380 & 19 & 2859 & 113 & 2 & 944 & 47 & 786 & 539 & 64 & 3 & 0.2 \\
\hline \multirow{2}{*}{ Irminger } & 44 & 443 & 1831 & 3 & 15 & 4 & 49 & 7 & 1 & 401 & 111 & 1281 & 147 & 1 & 512 & 142 & 809 & 996 & 5 & 14 & 4 \\
\hline & 51 & 9983 & 4558 & 4 & 76 & 5 & 312 & 2 & 7 & 2125 & 145 & 8128 & 200 & 1 & 3191 & 218 & 1983 & 3275 & 3 & 52 & 4 \\
\hline \multirow{3}{*}{ Labrador } & 64 & 3525 & 3049 & 6 & 30 & 2 & 203 & 4 & 1 & 3427 & 209 & 5812 & 160 & 3 & 966 & 59 & 2086 & 1976 & 20 & 8 & 0.5 \\
\hline & 69 & 969 & 3314 & 3 & 15 & 11 & 31 & 9 & 1 & 245 & 175 & 2150 & 129 & 1 & 996 & 713 & 294 & 1915 & 3 & 16 & 12 \\
\hline & 77 & 2621 & 4465 & 1 & 106 & 3 & 122 & 44 & 0.1 & 1873 & 57 & 3588 & 237 & 0.3 & 3442 & 105 & 864 & 5128 & 0.5 & 147 & 5 \\
\hline
\end{tabular}

\begin{tabular}{|c|c|c|c|c|c|c|c|c|c|c|c|c|c|c|c|c|}
\hline & & & & & & & & & & & & & & & & \\
\hline Basin & Station & diss. invent. & part. invent. & sinking rate & $\tau_{\text {tot }}$ & & diss. invent. & part. invent. & sinking rate & $\tau_{t}$ & & diss. invent. & part. invent. & sinking rate & $\tau_{t}$ & \\
\hline & & $\mu \mathrm{g} / \mathrm{m}^{2}$ & $\mu \mathrm{g} / \mathrm{m}^{2}$ & $\mathrm{~m} / \mathrm{d}$ & d & $\mathrm{sd}$ & $\mu \mathrm{g} / \mathrm{m}^{2}$ & $\mu \mathrm{g} / \mathrm{m}^{2}$ & $\mathrm{~m} / \mathrm{d}$ & d & sd & $\mu \mathrm{g} / \mathrm{m}^{2}$ & $\mu \mathrm{g} / \mathrm{m}^{2}$ & $\mathrm{~m} / \mathrm{d}$ & d & $\mathrm{sd}$ \\
\hline & 1 & 6726 & 408 & 12 & 130 & 6 & 8236 & 23 & 37 & 854 & 39 & 5769 & 1174 & 16 & 32 & 1 \\
\hline IDerian & 13 & 2606 & 332 & 1 & 664 & 70 & 11488 & 167 & 10 & 789 & 84 & 1355 & 951 & 4 & 67 & 7 \\
\hline Europ. & 26 & 2868 & 204 & 5 & 330 & 63 & 20682 & 194 & 1 & 12374 & 2369 & 1647 & 552 & 1 & 271 & 52 \\
\hline Jcelandi & 32 & 2505 & 175 & 9 & 212 & 26 & 19375 & 193 & 22 & 597 & 74 & 709 & 679 & 76 & 4 & 0.4 \\
\hline Tetativio & 38 & 1018 & 98 & 6 & 151 & 8 & 8152 & 88 & 11 & 674 & 33 & 790 & 400 & 22 & 11 & 0.1 \\
\hline Irminger & 44 & 361 & 312 & 1 & 89 & 25 & 3611 & 118 & 2 & 544 & 151 & 658 & 757 & 1 & 99 & 27 \\
\hline Labrador & 69 & 152 & 152 & 1 & 129 & 92 & 4705 & 202 & 1 & 1902 & 1361 & 464 & 345 & 3 & 33 & 24 \\
\hline & 77 & 53 & 461 & 0.1 & 2626 & 80 & 8 & 06 & 55 & 13297 & 407 & 3177 & 8 & 1 & 582 & 18 \\
\hline
\end{tabular}

Table 5: Dissolved inventories (diss. invent. from ${ }^{69,85}$ and from Planquette et al., personal communication, 2019), particulate inventories (part.

invent. from ${ }^{65}$ and from Planquette et al., personal communication, 2019), sinking rates calculated as the inverse of particle residence time multiplied by the Eq depth layer; total residence time ( $\tau_{\text {tot, }}$ in days) calculated by dividing the total inventory (dissolved+particulate) by the 
particulate flux and its standard deviation (sd) obtained by calculating $\tau_{\text {tot }}$ at Eq, Eq $+20 \mathrm{~m}$ or Eq-20m (20m being the average error on the determination of the Eq depth). 


\section{ASSOCIATED CONTENT}

\section{Supporting Information}

Figure S1: Summary of the different sampling and analytical steps for the $>53 \mu \mathrm{m}$ particle size fraction, collected on in-situ pump (ISP) filters and for total ${ }^{234} \mathrm{Th}$ activities, collected via standard CTD rosette. In this figure, each filter is defined by a nominal porosity (in $\mu \mathrm{m}$ ) and a diameter (corresponding to the symbol $\varnothing$, in $\mathrm{mm}$ ).

Figure S2: Mineral fluxes calculated either by using Al (top panel) or Ti (bottom panel) as lithogenic tracers (in $\mathrm{mg} / \mathrm{m}^{2} / \mathrm{d}$ ).

Figure S3: Vertical concentration profiles in the upper 400m (see Table S1 for deeper concentrations) of pTEs and minerals for the $>53 \mu \mathrm{m}$ size fraction along the GEOVIDE transect. There are three plots per element: Station \#1 (shown alone because of the extreme values observed for few elements); Iberian, west European and Icelandic basins; Irminger and Labrador basins.

Figure S4: Vertical profiles of pTE: ${ }^{234} \mathrm{Th}$ and mineral: ${ }^{234} \mathrm{Th}$ ratios in the upper $400 \mathrm{~m}$ for the large size fraction $(>53 \mu \mathrm{m})$ along the GEOVIDE transect. There are three plots per element: Station \#1 (shown alone because of the extreme values observed for few elements); Iberian, west European and Icelandic basins; Irminger and Labrador basins.

Figure S5: Concentration profiles of the $\mathrm{pFe}: \mathrm{pAl}(\mathrm{mol} / \mathrm{mol})$ and $\mathrm{pFe}: \mathrm{POC}(\mathrm{mmol} / \mathrm{mol})$ ratios, with the Eq depth (horizontal black dotted line), the pFe:pAl ratio in the UCC (vertical brown dashed line, from Taylor and McLenan, 1985) and the pFe:POC ratio in phytoplankton bulk (vertical green dashed line, from Twining et al., 2015). Ratios at Eq determined via the concentrations and the fluxes are indicated below each graph.

Table S1: Trace element concentrations (in $\mathrm{nmol} / \mathrm{L}$ ), mineral concentrations (in $\mu \mathrm{g} / \mathrm{L}$ ) and

${ }^{234} \mathrm{Th}$ activities (in dpm/L) for the large size fraction $(>53 \mu \mathrm{m})$ along the GEOVIDE transect. 
The (*) indicate depths where POC was collected using a separate ISP unit, 10 to $50 \mathrm{~m}$ apart from the ISP dedicated to TEs.

Table S2: Particulate TE: ${ }^{234} \mathrm{Th}$ (in nmol/dpm) and mineral: ${ }^{234} \mathrm{Th}$ (in $\mu \mathrm{g} / \mathrm{dpm}$ or ng/dpm) ratios in the large size fraction $(>53 \mu \mathrm{m})$, estimated at the Eq depth, along the GEOVIDE transect.

\section{AUTHOR INFORMATION}

\section{Corresponding Author}

* Nolwenn Lemaitre (nolwenn.lemaitre@erdw.ethz.ch)

\section{Author Contributions}

The manuscript was written through contributions of all authors. All authors have given approval to the final version of the manuscript.

\section{Notes}

The authors declare no competing financial interest.

\section{ACKNOWLEDGEMENTS}

We are grateful to the helpful captain and crew of the R/V Pourquoi Pas?, as well as to Fabien Perault and Emmanuel De Saint Léger from the CNRS DT-INSU who assisted during in situ pump deployments. Special thanks to Yi Tang (Queens College, USA), Virginie Sanial (WHOI, USA), Raphaëlle Sauzède (LOV, France) and Lorna Foliot (LSCE, France) for their help at sea and for the pump coordination and collaboration. We would also like to thank Phoebe Lam for providing two modified McLane ISP. Claire Bollinger from the Pôle Spectrométrie Océan (PSO, Brest, France) greatly helped during the element analysis by ICPMS. We acknowledge Yoan Germain and Emmanuel Ponzevera for the use of the clean lab at IFREMER. Finally, we would like to thank the co-chief scientist Pascale Lherminier. This 
work was funded by the French ANR Blanc GEOVIDE (ANR-13-BS06-0014), ANR RPDOC BITMAP (ANR-12-PDOC-0025-01), IFREMER, CNRS-INSU (programme LEFE), INSU OPTIMISP and Labex-Mer (ANR-10-LABX-19) and the Flanders Research Foundation (project G071512N) and Vrije Universiteit Brussel (Strategic Research Program, project SRP2). Satellite chlorophyll a data and visualisations used in this study were produced with the Ocean Color (Ocean Biology Processing Group; OBPG) online data system, developed and maintained by NASA.

\section{REFERENCES}

(1) Morel, F. M. M.; Price, N. M. The Biogeochemical Cycles of Trace Metals in the Oceans. Science (80-. ). 2003, 300 (5621), 944-947. https://doi.org/10.1126/science.1083545.

(2) Sunda, W. Trace Metal Interactions with Marine Phytoplankton. Biol. Oceanogr. 1989, 6, 411-442. https://doi.org/10.1080/01965581.1988.10749543.

(3) Twining, B. S.; Baines, S. B. The Trace Metal Composition of Marine Phytoplankton. Ann. Rev. Mar. Sci. 2013, 5, 191-215. https://doi.org/10.1146/annurev-marine121211-172322.

(4) Boyd, P. W.; Watson, a J.; Law, C. S.; Abraham, E. R.; Trull, T.; Murdoch, R.; Bakker, D. C.; Bowie, a R.; Buesseler, K. O.; Chang, H.; et al. A Mesoscale Phytoplankton Bloom in the Polar Southern Ocean Stimulated by Iron Fertilization. Nature 2000, 407 (6805), 695-702. https://doi.org/10.1038/35037500.

(5) Moore, C. M.; Mills, M. M.; Arrigo, K. R.; Berman-Frank, I.; Bopp, L.; Boyd, P. W.; Galbraith, E. D.; Geider, R. J.; Guieu, C.; Jaccard, S. L.; et al. Processes and Patterns of Oceanic Nutrient Limitation. Nat. Geosci. 2013, 6 (9), 701-710. https://doi.org/10.1038/ngeo1765.

(6) Martin, J. H. Glacial-Interglacial CO2 Change: The Iron Hypothesis. Paleoceanography 1990, 5, 1-13.

(7) Sigman, D. M.; Boyle, E. A. Glacial/Interglacial Variations in Atmospheric Carbon Dioxide. Nature 2000, 407 (October), 859-869.

(8) Jickells, T. D.; Baker, A. R.; Chance, R. Atmospheric Transport of Trace Elements and Nutrients to the Oceans. Philos. Trans. R. Soc. A 2016, 374, 1-19. https://doi.org/10.1098/rsta.2015.0286.

(9) de Baar, H. J. W.; Jong, J. T. Distributions, Sources and Sinks of Iron in Seawater. IUPAC Ser. analyitical Phys. Chem. Environ. Syst. 2001, 7, 123-254.

(10) Jeandel, C. Overview of the Mechanisms That Could Explain the 'Boundary Exchange' at the Land-Ocean Contact. Philos. Trans. R. Soc. A 2016, 374. https://doi.org/10.1098/rsta.2015.0287.

(11) Homoky, W. B.; Weber, T.; Berelson, W. M.; Conway, T. M.; Henderson, G. M.; van Hulten, M.; Jeandel, C.; Severmann, S.; Tagliabue, A. Quantifying Trace Element and Isotope Fluxes at the Ocean-Sediment Boundary: A Review. Philos. Trans. R. Soc. A 
2016, 374. https://doi.org/10.1098/rsta.2016.0246.

(12) Goldberg, E. D. Chemical Scavengers of the Sea. Chigaco Journals 1954, 62 (3), 249265.

(13) Dehairs, F.; Chesselet, R.; Jedwab, J. Discrete Suspended Particles of Barite and the Barium Cycle in the Open Ocean. Earth Planet. Sci. Lett. 1980, 49, 528-550.

(14) Bishop, J. K. B. The Barite-Opal-Organic Carbon Association in Oceanic Particulate Matter. Nature. 1988, pp 341-343. https://doi.org/10.1038/332341a0.

(15) Ganeshram, R. S.; François, R.; Commeau, J.; Brown-Leger, S. L. An Experimental Investigation of Barite Formation in Seawater. Geochim. Cosmochim. Acta 2003, 67 (14), 2599-2605. https://doi.org/10.1016/S0016-7037(03)00164-9.

(16) Bruland, K. W.; Lohan, M. C. Controls of Trace Metals in Seawater. In The oceans and marine geochemistry; Elderfield, H., Ed.; 2003; pp 23-47.

(17) Klaas, C.; Archer, D. E. Association of Sinking Organic Matter with Various Types of Mineral Ballast in the Deep Sea: Implications for the Rain Ratio. Global Biogeochem. Cycles 2002, 16 (4), 1-14. https://doi.org/10.1029/2001GB001765.

(18) Lam, P. J.; Bishop, J. K. B. The Continental Margin Is a Key Source of Iron to the HNLC North Pacific Ocean. Geophys. Res. Lett. 2008, 35 (7), 1-5. https://doi.org/10.1029/2008GL033294.

(19) Ohnemus, D. C.; Torrie, R.; Twining, B. S. Exposing the Distributions and Elemental Associations of Scavenged Particulate Phases in the Ocean Using Basin-Scale MultiElement Data Sets. Global Biogeochem. Cycles 2019, 33 (6), 725-748. https://doi.org/10.1029/2018GB006145.

(20) Puigcorbé, V.; Benitez-Nelson, C. R.; Masque, P.; Verdeny, E.; White, A.; Popp, B. N.; Prahl, F. G.; Lam, P. J. Small Phytoplankton Drive High Summertime Carbon and Nutrient Export in the Gulf of California and Eastern Tropical North Pacific. Glob. Planet. Change 2015, 29. https://doi.org/10.1002/2015GB005134.

(21) Giering, S. L. C.; Sanders, R.; Martin, A. P.; Lindemann, C.; Möller, K. O.; Daniels, C. J.; Mayor, D. J.; St. John, M. A. High Export via Small Particles before the Onset of the Nort Atlantic Spring Bloom. J. Geophys. Res. 2016, 121, 1-17. https://doi.org/10.1002/2016JC012048.Received.

(22) Fowler, S. W.; Knauer, G. a. Role of Large Particles in the Transport of Elements and Organic Compounds through the Oceanic Water Column. Prog. Oceanogr. 1986, 16 (3), 147-194. https://doi.org/10.1016/0079-6611(86)90032-7.

(23) Frew, R. D.; Hutchins, D. A.; Nodder, S.; Sanudo-Wilhelmy, S.; Tovar-Sanchez, A.; Leblanc, K.; Hare, C. E.; Boyd, P. W. Particulate Iron Dynamics during FeCycle in Subantarctic Waters Southeast of New Zealand. Global Biogeochem. Cycles 2006, 20 (1), 1-15. https://doi.org/10.1029/2005GB002558.

(24) Twining, B. S.; Nodder, S. D.; King, A. L.; Hutchins, D. A.; LeCleir, G. R.; DeBruyn, J. M.; Maas, E. W.; Vogt, S.; Wilhelm, S. W.; Boyd, P. W. Differential Remineralization of Major and Trace Elements in Sinking Diatoms. Limnol. Oceanogr. 2014, 59 (3), 689-704. https://doi.org/10.4319/lo.2014.59.3.0689.

(25) Hayes, C. T.; Anderson, R. F.; Cheng, H.; Conway, T. M.; Edwards, R. L.; Fleisher, M. Q.; Ho, P.; Huang, K. F.; John, S. G.; Landing, W. M.; et al. Replacement Times of a Spectrum of Elements in the North Atlantic Based on Thorium Supply. Global Biogeochem. Cycles 2018, 32 (9), 1294-1311. https://doi.org/10.1029/2017GB005839.

(26) Ellwood, M. J.; Nodder, S. D.; King, A. L.; Hutchins, D. A.; Wilhelm, S. W.; Boyd, P. W. Pelagic Iron Cycling during the Subtropical Spring Bloom, East of New Zealand. Mar. Chem. 2014, 160 (MARCH), 18-33. 
https://doi.org/10.1016/j.marchem.2014.01.004.

(27) Ho, T.; Chou, W.; Wei, C.; Lin, F.; Wong, G. T. F.; Lin, H.-L. Trace Metal Cycling in the Surface Water of the South China Sea: Vertical Fluxes, Composition, and Sources. Limnol. Oceanogr. 2010, 55 (5), 1807-1820. https://doi.org/10.4319/lo.2010.55.5.1807.

(28) Kuss, J.; Waniek, J. J.; Kremling, K.; Schulz-bull, D. E. Seasonality of ParticleAssociated Trace Element Fluxes in the Deep Northeast Atlantic Ocean. Deep Sea Res. Part I Oceanogr. Res. Pap. 2010, 57 (6), 785-796. https://doi.org/10.1016/j.dsr.2010.04.002.

(29) Kuss, J.; Kremling, K. Particulate Trace Element Fluxes in the Deep Northeast Atlantic Ocean. Deep Sea Res. Part I Oceanogr. Res. Pap. 1999, 46 (1), 149-169. https://doi.org/10.1016/S0967-0637(98)00059-4.

(30) Lamborg, C. H.; Buesseler, K. O.; Lam, P. J. Sinking Fluxes of Minor and Trace Elements in the North Pacific Ocean Measured during the VERTIGO Program. Deep Sea Res. Part II Top. Stud. Oceanogr. 2008, 55 (14-15), 1564-1577. https://doi.org/10.1016/j.dsr2.2008.04.012.

(31) Lemaitre, N.; Planquette, H.; Dehairs, F.; van der Merwe, P.; Bowie, A. R.; Trull, T. W.; Laurenceau-Cornec, E. C.; Davies, D.; Bollinger, C.; Le Goff, M.; et al. Impact of the Natural Fe-Fertilization on the Magnitude, Stoichiometry and Efficiency of Particulate Biogenic Silica, Nitrogen and Iron Export Fluxes. Deep. Res. Part I Oceanogr. Res. Pap. 2016, 117, 11-27. https://doi.org/10.1016/j.dsr.2016.09.002.

(32) Planquette, H.; Sanders, R.; Statham, P. J.; Morris, P. J.; Fones, G. R. Fluxes of Particulate Iron from the Upper Ocean around the Crozet Islands: A Naturally IronFertilized Environment in the Southern Ocean. Global Biogeochem. Cycles 2011, 25 (2), 1-12. https://doi.org/10.1029/2010GB003789.

(33) Stanley, R. H. R.; Buesseler, K. O.; Manganini, S. J.; Steinberg, D. K.; Valdes, J. R. A Comparison of Major and Minor Elemental Fluxes Collected in Neutrally Buoyant and Surface-Tethered Sediment Traps. Deep Sea Res. Part I Oceanogr. Res. Pap. 2004, 51, 1387-1395. https://doi.org/10.1016/j.dsr.2004.05.010.

(34) Weinstein, S. E.; Moran, S. B. Vertical Flux of Particulate Al, Fe, Pb, and Ba from the Upper Ocean Estimated from 234Th/238U Disequilibria. Deep Sea Res. Part I Oceanogr. Res. Pap. 2005, 52 (8), 1477-1488. https://doi.org/http://dx.doi.org/10.1016/j.dsr.2005.03.008.

(35) Black, E. E.; Kienast, S. S.; Lemaitre, N.; Lam, P. J.; Anderson, R. F.; Planquette, H.; Planchon, F.; Buesseler, K. O. Ironing out Fe Residence Time in the Dynamic Upper Ocean. Global Biogeochem. Cycles 2020, 34, 1-17. https://doi.org/10.1029/2020GB006592.

(36) Black, E. E.; Lam, P. J.; Lee, J. M.; Buesseler, K. O. Insights from the 238U- 234Th Method into the Coupling of Biological Export and the Cycling of Cadmium, Cobalt, and Manganese in the Southeast Pacific Ocean. Global Biogeochem. Cycles 2019, 33 (1), 15-36. https://doi.org/10.1029/2018GB005985.

(37) Benitez-Nelson, C. R.; Bidigare, R.; Dickey, T. D.; Landry, M. R.; Leonard, C. L.; Brown, S. L.; Nencioli, F.; Rii, Y. M.; Maiti, K.; Becker, J. W.; et al. Mesoscale Eddies Drive Increased Silica Export in the Subtropical Pacific Ocean. Science (80-. ). 2007, 316, 1017-1022. https://doi.org/10.1126/science.1136221.

(38) Conte, M. H.; Carter, A. M.; Koweek, D. A.; Huang, S.; Weber, J. C. The Elemental Composition of the Deep Particle Flux in the Sargasso Sea. Chem. Geol. 2019, 511 (October 2018), 279-313. https://doi.org/10.1016/j.chemgeo.2018.11.001. 
(39) McDonnell, A. M. P.; Lam, P. J.; Lamborg, C. H.; Buesseler, K. O.; Sanders, R.; Riley, J. S.; Marsay, C.; Smith, H. E. K.; Sargent, E. C.; Lampitt, R. S.; et al. The Oceanographic Toolbox for the Collection of Sinking and Suspended Marine Particles. Prog. Oceanogr. 2015, 133, 17-31. https://doi.org/10.1016/j.pocean.2015.01.007.

(40) Coale, K. H.; Bruland, K. W. Thorium-234:Uranium-238 Disequilibria within the California Current. Limnol. Oceanogr. 1985, 30 (1), 22-33.

https://doi.org/10.4319/lo.1985.30.1.0022.

(41) Buesseler, K. O.; Bacon, M. P.; Kirk Cochran, J.; Livingston, H. D. Carbon and Nitrogen Export during the JGOFS North Atlantic Bloom Experiment Estimated from 234Th: 238U Disequilibria. Deep Sea Res. Part A. Oceanogr. Res. Pap. 1992, 39 (78), 1115-1137. https://doi.org/10.1016/0198-0149(92)90060-7.

(42) Cochran, J. K.; Masqué, P. Short-Lived U/Th Series Radionuclides in the Ocean: Tracers for Scavenging Rates, Export Fluxes and Particle Dynamics. Rev. Mineral. Geochemistry 2003, 52, 461-492. https://doi.org/10.2113/0520461.

(43) Kuss, J.; Kremling, K. Spatial Variability of Particle Associated Trace Elements in Near-Surface Waters of the North Atlantic $\left(30^{\circ} \mathrm{N} / 60^{\circ} \mathrm{W}\right.$ to $\left.60^{\circ} \mathrm{N} / 2^{\circ} \mathrm{W}\right)$, Derived by Large Volume Sampling. Mar. Chem. 1999, 68 (1-2), 71-86. https://doi.org/10.1016/S0304-4203(99)00066-3.

(44) Ohnemus, D. C.; Lam, P. J. Cycling of Lithogenic Marine Particulates in the US GEOTRACES North Atlantic Transect. Deep Sea Res. Part II Top. Stud. Oceanogr. 2014, 116 (November 2015), 283-302. https://doi.org/http://dx.doi.org/10.1016/j.dsr2.2014.11.019.

(45) Pohl, C.; Croot, P. L.; Hennings, U.; Daberkow, T.; Budeus, G.; Rutgers van der Loeff, M. M. Synoptic Transects on the Distribution of Trace Elements $(\mathrm{Hg}, \mathrm{Pb}, \mathrm{Cd}, \mathrm{Cu}, \mathrm{Ni}$, $\mathrm{Zn}, \mathrm{Co}, \mathrm{Mn}, \mathrm{Fe}$, and $\mathrm{Al}$ ) in Surface Waters of the Northern- and Southern East Atlantic. J. Mar. Syst. 2011, 84 (1-2), 28-41. https://doi.org/10.1016/j.jmarsys.2010.08.003.

(46) Saito, M. A.; Noble, A. E.; Hawco, N.; Twining, B. S.; Ohnemus, D. C.; John, S. G.; Lam, P.; Conway, T. M.; Johnson, R.; Moran, D.; et al. The Acceleration of Dissolved Cobalt's Ecological Stoichiometry Due to Biological Uptake, Remineralization, and Scavenging in the Atlantic Ocean. Biogeosciences 2017, 14 (20), 4637-4662. https://doi.org/10.5194/bg-14-4637-2017.

(47) Weinstein, S. E.; Moran, S. B. Distribution of Size-Fractionated Particulate Trace Metals Collected by Bottles and in-Situ Pumps in the Gulf of Maine-Scotian Shelf and Labrador Sea. Mar. Chem. 2004, 87 (3-4), 121-135. https://doi.org/10.1016/j.marchem.2004.02.004.

(48) Nielsdottir, M. C.; Moore, C. M.; Sanders, R.; Hinz, D. J.; Achterberg, E. P. Iron Limitation of the Postbloom Phytoplankton Communities in the Iceland Basin. Global Biogeochem. Cycles 2009, 23, 1-13. https://doi.org/10.1029/2008GB003410.

(49) Achterberg, E. P.; Moore, C. M.; Henson, S. A.; Steigenberger, S.; Stohl, A.; Eckhardt, S.; Avendano, L. C.; Cassidy, M.; Hembury, D.; Klar, J. K.; et al. Natural Iron Fertilization by the Eyjafjallajökull Volcanic Eruption. Geophys. Res. Lett. 2013, 40, 921-926. https://doi.org/10.1002/grl.50221.

(50) Blain, S.; Guieu, C.; Claustre, H.; Leblanc, K.; Moutin, T.; Guiner, B. Q.; Ras, J.; Sarthou, G. Availability of Iron and Major Nutrients for Phytoplankton in the NorthEast Atlantic Ocean. Limnol. Oceanogr. 2004, 49 (6), 2095-2104. https://doi.org/10.4319/lo.2004.49.6.2095.

(51) Moore, C. M.; Mills, M. M.; Langlois, R.; Milne, A.; Achterberg, E. P.; Roche, J. La; 
Geider, R. J. Relative Influence of Nitrogen and Phosphorus Availability on Phytoplankton Physiology and Productivity in the Oligotrophic Sub-Tropical North Atlantic Ocean. Limnol. Oceanogr. 2008, 53 (1), 291-305.

(52) Owens, S. A.; Pike, S.; Buesseler, K. O. Thorium-234 as a Tracer of Particle Dynamics and Upper Ocean Export in the Atlantic Ocean. Deep Sea Res. Part II Top. Stud. Oceanogr. 2014, 116, 42-59. https://doi.org/10.1016/j.dsr2.2014.11.010.

(53) Thomalla, S.; Turnewitsch, R.; Lucas, M.; Poulton, A. Particulate Organic Carbon Export from the North and South Atlantic Gyres: The 234Th/238U Disequilibrium Approach. Deep Sea Res. Part II Top. Stud. Oceanogr. 2006, 53, 1629-1648. https://doi.org/10.1016/j.dsr2.2006.05.018.

(54) Antia, N.; Peinert, R.; Hebbeln, D.; Bathmann, U.; Fehner, U.; Zeitzschel, B. BasinWide Particulate Carbon Flux in the Atlantic Ocean ' Regional Export Patterns and Potential for Atmospheric Sequestration Avan Detlef TM Jan s Susanne Regional Differences in Changes of the Export Ratio with Depth Are Related to over the Atlantic Oc. Global Biogeochem. Cycles 2001, 15 (4), 845-862. https://doi.org/10.1029/2000gb001376.

(55) Billet, D. S. M.; Lampitt, R. S.; Rice, A. L.; Mantoura, R. F. C. Seasonal Sedimentation of Phytoplankton to the Deep-Sea Benthos. Nature 1983, 302.

(56) Henson, S. A.; Dunne, J. P.; Sarmiento, J. L. Decadal Variability in North Atlantic Phytoplankton Blooms. J. Geophys. Res. 2009, 114 (C4), C04013-C04013. https://doi.org/10.1029/2008JC005139.

(57) Lampitt, R. S.; Salter, I.; de Cuevas, B. A.; Hartman, S.; Larkin, K. E.; Pebody, C. A. Long-Term Variability of Downward Particle Flux in the Deep Northeast Atlantic: Causes and Trends. Deep Sea Res. Part II Top. Stud. Oceanogr. 2010, 57 (15), 13461361. https://doi.org/10.1016/j.dsr2.2010.01.011.

(58) Peinert, R.; Antia, A. N.; Bauerfeind, E.; v. Bodungen, B.; Haupt, O.; Krumbholz, M.; Peeken, I.; Ramseier, R. O.; Voss, M.; Zeitzschel, B. Particle Flux Variability in the Polar and Atlantie Biogeoehemieal Provinees of the Nordie Seas. North. North Atl. 2001, 53-68.

(59) Lam, P. J.; Ohnemus, D. C.; Auro, M. E. Size-Fractionated Major Particle Composition and Concentrations from the US GEOTRACES North Atlantic Zonal Transect. Deep Sea Res. Part II Top. Stud. Oceanogr. 2015, 116, 303-320. https://doi.org/10.1016/j.dsr2.2014.11.020.

(60) Lemaitre, N.; Planchon, F.; Planquette, H.; Dehairs, F.; Fonseca-Batista, D.; Roukaerts, A.; Deman, F.; Mariez, C.; Sarthou, G. High Variability of Export Fluxes along the North Atlantic GEOTRACES Section GA01: Particulate Organic Carbon Export Deduced from the 234Th Method. Biogeosciences 2018, 15 (21), 6417-6437. https://doi.org/10.5194/bg-15-2289-2018.

(61) Fonseca-Batista, D.; Li, X.; Riou, V.; Michotey, V.; Deman, F.; Fripiat, F.; Guasco, S.; Brion, N.; Lemaitre, N.; Tonnard, M.; et al. Evidence of High N2 Fixation Rates in the Temperate Northeast Atlantic. Biogeosciences 2019, 16, 999-1017. https://doi.org/10.5194/bg-16-999-2019.

(62) Tonnard, M. Etude Du Cycle Biogéochimique Du Fer : Distribution et Spéciation Dans l'océan Atlantique Nord (GA01) et l'océan Austral (GIpr05) (GEOTRACES), Université de Bretagne Occidentale \& Université de Tasmanie, 2018.

(63) Pike, S.; Buesseler, K. O.; Andrews, J.; Savoye, N. Quantification of 234Th Recovery in Small Volume Seawater Samples by Inductively Coupled Plasma Mass Spectrometry. J. Radioanal. Nucl. Chem. 2005, 263, 355-360. 
(64) Savoye, N.; Benitez-Nelson, C.; Burd, A. B.; Cochran, J. K.; Charette, M.; Buesseler, K. O.; Jackson, G. A.; Roy-Barman, M.; Schmidt, S.; Elskens, M. 234Th Sorption and Export Models in the Water Column: A Review. Mar. Chem. 2006, 100, 234-249. https://doi.org/10.1016/j.marchem.2005.10.014.

(65) Gourain, A.; Planquette, H.; Cheize, M.; Lemaitre, N.; Menzel Barraqueta, J. L.; Shelley, R.; Lherminier, P.; Planquette, H. Inputs and Processes Affecting the Distribution of Particulate Iron in the North Atlantic along the GEOVIDE (GEOTRACES GA01) Section. Biogeosciences 2019, 16 (7), 1563-1582. https://doi.org/10.5194/bg-16-1563-2019.

(66) Planquette, H.; Sherrell, R. M. Sampling for Particulate Trace Element Determination Using Water Sampling Bottles: Methodology and Comparison to in Situ Pumps.

Limnol. Oceanogr. Methods 2012, 10, 367-388. https://doi.org/10.4319/lom.2012.10.367.

(67) Taylor, S. R.; Mclennan, S. M. The Continental Crust: Its Composition and Evolution, Blackwell,.; 1985.

(68) Moran, S. B.; Moore, R. M. Evidence from Mesocosm Studies for Biological Removal of Dissolved Aluminium from Sea Water. Nature 1988, 335 (6192), 706-708. https://doi.org/10.1038/335706a0.

(69) Menzel Barraqueta, J.-L.; Schlosser, C.; Planquette, H.; Gourain, A.; Cheize, M.; Boutorh, J.; Shelley, R.; Pereira Contraira, L.; Gledhill, M.; Hopwood, M. J.; et al. Aluminium in the North Atlantic Ocean and the Labrador Sea (GEOTRACES GA01 Section): Roles of Continental Inputs and Biogenic Particle Removal. Biogeosciences 2018, 15, 5271-5286. https://doi.org/10.5194/bg-15-5271-2018.

(70) Lam, P. J.; Lee, J. M.; Heller, M. I.; Mehic, S.; Xiang, Y.; Bates, N. R. SizeFractionated Distributions of Suspended Particle Concentration and Major Phase Composition from the U.S. GEOTRACES Eastern Pacific Zonal Transect (GP16). Mar. Chem. 2018, 201 (April), 90-107. https://doi.org/10.1016/j.marchem.2017.08.013.

(71) Twining, B. S.; Rauschenberg, S.; Morton, P. L.; Vogt, S. Metal Contents of Phytoplankton and Labile Particulate Material in the North Atlantic Ocean. Prog. Oceanogr. 2015, 137, 261-283. https://doi.org/10.1016/j.pocean.2015.07.001.

(72) Broecker, W.; Peng, T. Tracers in the Sea, Lamont-Doh.; 1982.

(73) Ragueneau, O.; Savoye, N.; Del Amo, Y.; Cotten, J.; Tardiveau, B.; Leynaert, A. A New Method for the Measurement of Biogenic Silica in Suspended Matter of Coastal Waters: Using Si:Al Ratios to Correct for the Mineral Interference. Cont. Shelf Res. 2005, 25 (5-6), 697-710. https://doi.org/10.1016/j.csr.2004.09.017.

(74) Aminot, A.; Kérouel, R. Dosage Automatique Des Nutriments Dans Les Eaux Marines: Méthodes En Flux Continu, Ifremer-Qu.; 2007.

(75) Hydes, D. J.; Liss, P. S. Fluorimetric Method for the Determination of Low Concentrations of Dissolved Aluminium in Natural Waters. Analyst 1976, 101, 922931.

(76) Mortlock, R. A.; Froelich, P. N. A Simple Method for the Rapid Determination of Biogenic Opal in Pelagic Marine Sediments. Deep Sea Res. Part A, Oceanogr. Res. Pap. 1989, 36 (9), 1415-1426. https://doi.org/10.1016/0198-0149(89)90092-7.

(77) Bishop, J. K. B.; Edmond, J. M.; Ketten, D. R.; Bacon, M. P.; Silker, W. B. The Chemistry, Biology and Vertical Flux of Particulate Matter from the Upper 400m of the Equatorial Atlantic Ocean. Deep Sea Res. Part A, Oceanogr. Res. Pap. 1977, 24 (6), 511-548. 
(78) Michaels, A. F.; Silver, M. W. Primary Production, Sinking Fluxes and the Microbial Food Web. Deep Sea Res. Part A. Oceanogr. Res. Pap. 1988, 35 (4), 473-490.

(79) Villa-Alfageme, M.; Soto, F. C.; Ceballos, E.; Giering, S. L. C.; Le Moigne, F. A. C.; Henson, S.; Mas, J. L.; Sanders, R. J. Geographical, Seasonal and Depth Variation in Sinking Particle Speeds in the North Atlantic. Geophys. Res. Lett. 2016, 43, 86098616. https://doi.org/10.1002/2016GL069233.Received.

(80) Le Moigne, F. A. C.; Villa-Alfageme, M.; Sanders, R. J.; Marsay, C.; Henson, S.; García-Tenorio, R. Export of Organic Carbon and Biominerals Derived from 234Th and 210Po at the Porcupine Abyssal Plain. Deep Sea Res. Part I Oceanogr. Res. Pap. 2013, 72 (August), 88-101. https://doi.org/10.1016/j.dsr.2012.10.010.

(81) Planchon, F.; Ballas, D.; Cavagna, A.-J.; Bowie, A. R.; Davies, D. M.; Trull, T.; Laurenceau, E. C.; van der Merwe, P.; Dehairs, F. Carbon Export in the Naturally Iron-Fertilized Kerguelen Area of the Southern Ocean Based on the 234 Th Approach. Biogeosciences 2015, 12, 3831-3848. https://doi.org/10.5194/bgd-12-3831-2015.

(82) Puigcorbé, V.; Roca-Martí, M.; Masqué, P.; Benitez-Nelson, C.; Rutgers van der Loeff, M.; Bracher, A.; Moreau, S. Latitudinal Distributions of Particulate Carbon Export across the North Western Atlantic Ocean. Deep Sea Res. Part I Oceanogr. Res. Pap. 2017. https://doi.org/10.1016/j.dsr.2017.08.016.

(83) Black, E. E.; Buesseler, K. O.; Pike, S. M.; Lam, P. J. 234Th as a Tracer of Particulate Export and Remineralization in the Southeastern Tropical Pacific. Mar. Chem. 2018, 201, 35-50. https://doi.org/10.1016/j.marchem.2017.06.009.

(84) Durkin, C. A.; Estapa, M. L.; Buesseler, K. O. Observations of Carbon Export by Small Sinking Particles in the Upper Mesopelagic. Mar. Chem. 2015, 175, 72-81. https://doi.org/10.1016/j.marchem.2015.02.011.

(85) Tonnard, M.; Planquette, H.; Bowie, A. R.; van der Merwe, P.; Gallinari, M.; Desprez de Gésincourt, F.; Germain, Y.; Gourain, A.; Benetti, M.; Reverdin, G.; et al. Dissolved Iron in the North Atlantic Ocean and Labrador Sea along the GEOVIDE Section (GEOTRACES Section GA01). Biogeosciences 2020, 14, 917-943. https://doi.org/10.5194/bg-17-917-2020.

(86) Planquette, H.; Fones, G. R.; Statham, P. J.; Morris, P. J. Origin of Iron and Aluminium in Large Particles ( $>53 \mathrm{Mm})$ in the Crozet Region, Southern Ocean. Mar. Chem. 2009, 115 (1-2), 31-42. https://doi.org/DOI 10.1016/j.marchem.2009.06.002.

(87) Schlitzer, R.; Anderson, R. F.; Masferrer Dodas, E.; Lohan, M. C.; Geibert, W.; Tagliabue, A.; Bowie, A. R.; Jeandel, C.; Maldonado, M. T.; Landing, W. M.; et al. The GEOTRACES Intermediate Data Product 2017. Chem. Geol. 2018, 493 (June), 210-223. https://doi.org/10.1016/j.chemgeo.2018.05.040.

(88) Smith, J. N.; Yeats, P. A.; Knowlton, S. E.; Moran, S. B. Comparison of 234Th/238U and Mass Balance Models for Estimating Metal Removal Fluxes in the Gulf of Maine and Scotian Shelf. Cont. Shelf Res. 2014, 77, 107-117. https://doi.org/10.1016/j.csr.2014.01.008.

(89) Buesseler, K. O.; Benitez-Nelson, C. R.; Moran, S. B.; Burd, a.; Charette, M.; Cochran, J. K.; Coppola, L.; Fisher, N. S.; Fowler, S. W.; Gardner, W. D.; et al. An Assessment of Particulate Organic Carbon to Thorium-234 Ratios in the Ocean and Their Impact on the Application of 234Th as a POC Flux Proxy. Mar. Chem. 2006, 100 (3-4 SPEC. ISS.), 213-233. https://doi.org/10.1016/j.marchem.2005.10.013.

(90) Shelley, R. U.; Roca-Martí, M.; Castrillejo, M.; Masqué, P.; Landing, W. M.; Planquette, H.; Sarthou, G. Quantification of Trace Element Atmospheric Deposition Fluxes to the Atlantic Ocean ( $>40^{\circ} \mathrm{N}$; GEOVIDE, GEOTRACES GA01) during Spring 
2014. Deep. Res. Part I Oceanogr. Res. Pap. 2017, 119 (November), 34-49. https://doi.org/10.1016/j.dsr.2016.11.010.

(91) Leinen, M.; Pisias, N. An Objective Technique for Determining End-Member Compositions and for Partitioning Sediments According to Their Sources. Geochim. Cosmochim. Acta 1984, 48 (1), 47-62. https://doi.org/10.1016/0016-7037(84)90348$\mathrm{X}$.

(92) Templ, M.; Filzmoser, P.; Reimann, C. Cluster Analysis Applied to Regional Geochemical Data: Problems and Possibilities. Appl. Geochemistry 2008, 23 (8), 2198-2213. https://doi.org/10.1016/j.apgeochem.2008.03.004.

(93) Takematsu, N. Sorption of Transition Metals on Manganese and Iron Oxides, and Solicate Minerals. J. Oceanogr. Soc. Japan 1979, 35, 36-42.

(94) Duarte, B.; Caçador, I. Particulate Metal Distribution in Tagus Estuary (Portugal) during a Flood Episode. Mar. Pollut. Bull. 2012, 64 (10), 2109-2116. https://doi.org/10.1016/j.marpolbul.2012.07.016.

(95) Cotté-Krief, M.-H.; Guieu, C.; Thomas, A. J.; Martin, J.-M. Sources of Cd, Cu, Ni and $\mathrm{Zn}$ in Portuguese Coastal Waters. Mar. Chem. 2000, 71, 199-214.

(96) Duarte, B.; Silva, G.; Lino, J.; Paulo, J.; Azeda, C.; Sá, E.; Metelo, I.; José, M.; Caçador, I. Heavy Metal Distribution and Partitioning in the Vicinity of the Discharge Areas of Lisbon Drainage Basins (Tagus Estuary , Portugal). J. Sea Res. 2014, 93, 101-111. https://doi.org/10.1016/j.seares.2014.01.003.

(97) Caçador, I.; Vale, C.; Catarino, F. Accumulation of $\mathrm{Zn}, \mathrm{Pb}, \mathrm{Cu}, \mathrm{Cr}$ and $\mathrm{Ni}$ in Sediments between Roots of the Tagus Estuary Salt Marshes, Portugal. Estuar. Coast. Shelf Sci. 1996, 42, 393-403.

(98) Le Gall, A. C.; Statham, P. J.; Morley, N. J.; Hydes, D. J.; Hunt, C. H. Processes Influencing Distributions and Concentrations of $\mathrm{Cd}, \mathrm{Cu}, \mathrm{Mn}$ and $\mathrm{Ni}$ at the North West European Shelf Break. Mar. Chem. 1999, 68, 97-115.

(99) Ye, Y.; Völker, C. On the Role of Dust-Deposited Lithogenic Particles for Iron Cycling in the Tropical and Subtropical Atlantic. Global Biogeochem. Cycles 2017, 31 (10), 1543-1558. https://doi.org/10.1002/2017GB005663.

(100) Tagliabue, A.; Bowie, A. R.; Boyd, P. W.; Buck, K. N.; Johnson, K. S.; Saito, M. A. The Integral Role of Iron in Ocean Biogeochemistry. Nature 2017, 543 (7643), 51-59. https://doi.org/10.1038/nature21058.

(101) Lagarde, M.; Lemaitre, N.; Planquette, H.; Grenier, M.; Belhadj, M.; Jeandel, C. Particulate Rare Earth Element Behavior in the North Atlantic ( GEOVIDE Cruise ). Biogeosciences Discuss. 2020, No. January, 1-32. https://doi.org/10.5194/bg-2019462.

(102) van Weering, T. C. E.; de Stigter, H. C.; Boer, W.; de Haas, H. Recent Sediment Transport and Accumulation on the NW Iberian Margin. Prog. Earth Planet. Sci. 2002, 52, 349-371.

(103) McCave, I. N.; Hall, I. R. Turbidity of Waters over the Northwest Iberian Continental Margin. Prog. Oceanogr. 2002, 52 (2-4), 299-313. https://doi.org/10.1016/S00796611(02)00012-5.

(104) Moffett, J. W.; Ho, J. Oxidation of Cobalt and Manganese in Seawater via a Common Microbially Catalyzed Pathway. Geochim. Cosmochim. Acta 1996, 60 (18), 34153424.

(105) Zunino, P.; Lherminier, P.; Mercier, H.; Daniault, N.; García-Ibáñez, M. I.; Pérez, F. F. The GEOVIDE Cruise in May-June 2014 Reveals an Intense Meridional Overturning Circulation over a Cold and Fresh Subpolar North Atlantic. Biogeosciences 2017, 14 
(23), 5323-5342. https://doi.org/10.5194/bg-14-5323-2017.

(106) Van Hulten, M.; Middag, R.; Dutay, J. C.; De Baar, H.; Roy-Barman, M.; Gehlen, M.; Tagliabue, A.; Sterl, A. Manganese in the West Atlantic Ocean in the Context of the First Global Ocean Circulation Model of Manganese. Biogeosciences 2017, 14 (5), 1123-1152. https://doi.org/10.5194/bg-14-1123-2017.

(107) John, S. G.; Conway, T. M. A Role for Scavenging in the Marine Biogeochemical Cycling of Zinc and Zinc Isotopes. Earth Planet. Sci. Lett. 2014, 394, 159-167. https://doi.org/10.1016/j.epsl.2014.02.053.

(108) Twining, B. S.; Rauschenberg, S.; Morton, P. L.; Ohnemus, D. C.; Lam, P. J. Comparison of Particulate Trace Element Concentrations in the North Atlantic Ocean as Determined with Discrete Bottle Sampling and in Situ Pumping. Deep Sea Res. Part II Top. Stud. Oceanogr. 2015, 116, 273-282. https://doi.org/10.1016/j.dsr2.2014.11.005.

(109) Collier, R.; Edmond, J. The Trace Element Geochemistry of Marine Biogenic Particulate Matter. Prog. Oceanogr. 1984, 13, 113-199.

(110) King, a. L.; Sañudo-Wilhelmy, S. a.; Boyd, P. W.; Twining, B. S.; Wilhelm, S. W.; Breene, C.; Ellwood, M. J.; Hutchins, D. a. A Comparison of Biogenic Iron Quotas during a Diatom Spring Bloom Using Multiple Approaches. Biogeosciences 2012, 9 (2), 667-687. https://doi.org/10.5194/bg-9-667-2012.

(111) Muggli, D. L.; Harrison, P. J. Effects of Nitrogen Source on the Physiology and Metal Nutrition of Emiliania Huxleyi Grown under Different Iron and Light Conditions. Mar. Ecol. Prog. Ser. 1996, 130 (Raven 1988), 255-267.

(112) Muggli, D. L.; Lecourt, M.; Harrison, P. J. Effects of Iron and Nitrogen Source on the Sinking Rate, Physiology and Metal Composition of an Oceanic Diatom from the Subarctic Pacific. Mar. Ecol. Prog. Ser. 1996, 132, 215-227.

(113) Sunda, W. G.; Huntsman, S. A. Iron Uptake and Growth Limitation in Oceanic and Coastal Phytoplankton. Mar. Chem. 1995, 50, 189-206.

(114) Lemaitre, N.; Planquette, H.; Planchon, F.; Sarthou, G.; Jacquet, S.; García-Ibáñez, M. I.; Gourain, A.; Cheize, M.; Monin, L.; André, L.; et al. Particulate Barium Tracing Significant Mesopelagic Carbon Remineralisation in the North Atlantic.

Biogeosciences 2018, 15, 2289-2307. https://doi.org/10.5194/bg-15-2289-2018.

(115) Boiteau, R. M.; Mende, D. R.; Hawco, N. J.; McIlvin, M. R.; Fitzsimmons, J. N.; Saito, M. A.; Sedwick, P. N.; Delong, E. F.; Repeta, D. J. Siderophore-Based Microbial Adaptations to Iron Scarcity across the Eastern Pacific Ocean. Proc. Natl. Acad. Sci. U. S. A. 2016, 113 (50), 14237-14242. https://doi.org/10.1073/pnas.1608594113.

(116) Maerz, J.; Six, K. D.; Stemmler, I.; Ahmerkamp, S.; Ilyina, T. Microstructure and Composition of Marine Aggregates as Co-Determinants for Vertical Particulate Organic Carbon Transfer in the Global Ocean. Biogeosciences 2020, 17 (7), 17651803. https://doi.org/10.5194/bg-17-1765-2020.

(117) García-Ibáñez, M. I.; Pérez, F. F.; Lherminier, P.; Zunino, P.; Mercier, H.; Tréguer, P. Water Mass Distributions and Transports for the 2014 GEOVIDE Cruise in the North Atlantic. Biogeosciences 2018, 15 (7), 2075-2090. https://doi.org/10.5194/bg-152075-2018. 